\title{
Belediyelerin E-Yönetişim Hizmetlerine Yönelik Yurttaşların Bilgi, Farkındalık ve Kullanım Düzeyleri: Kocaeli İli Örneği ${ }^{1}$
}

\author{
Citizen's Knowledge, Awareness and Usage Levels for E-Governance Services of Municipalities: The \\ Case of Kocaeli Province
}

\section{İdil SAYIMER}

Prof. Dr., Kocaeli Üniversitesi, Iletişim Fakültesi,

Halkla İlişkiler ve Tanıtım Bölümü,

sayimeri@gmail.com

https://orcid.org/0000-0002-2250-8900

\author{
Banu KÜC̋̈KSARAÇ \\ Dr. Öğr. Üyesi, Kocaeli Üniversitesi, Iletişim Fakültesi, \\ Halkla Illișkiler ve Tanıtım Bölümü, \\ bksarac@gmail.com \\ https://orcid.org/0000-0001-6216-9045
}

Makale Başvuru Tarihi: 29.07.2019

Makale Kabul Tarihi: 05.09.2019

Makale Türü: Araştırma Makalesi

\begin{abstract}
Anahtar
Kelimeler:

E-Yönetişim,

Belediye,

Yurttaş,

Kocaeli, şekillendirilmesi, uygulanması ve denetlenmesinde devlet-vatandaş etkileşimine odaklanan e-yönetişim, kamusal hizmet sunumunun yerel düzeydeki en önemli temsilcileri olan belediyeler ve yurttaşlar için olumlu kazanımlar sağlamaktadır. Belediyeler ve yurttaşlar açısından olumlu kazanımlar sağlayan e-yönetişim uygulamalarının her iki tarafa da fayda sağlayacak biçimde geliştirilip sürdürülmesine katkı sunmak amacıyla yurttaşlar tarafindan bilgi, farkındallk ve kullanım düzeylerinin belirlenmesi gerekmektedir. Bu çalışma; Kocaeli il ve ilçe belediyelerinin yeni medya ortamlarında sunmuş oldukları hizmetleri e-yönetişim çerçevesinde beledive ve yurttaș açısından incelemeye yönelik yapılan TÜBİTAK-117K012 projesine ait araştırmanın kesitsel bir bölümünü yansitmaktadır. Araştırmada, Kocaeli il ve ilçe belediyelerinin eyönetişim bağlamında yeni medya ortamlarında sundukları hizmetlere yönelik yurttaşların bilgi, farkındalık ve kullanım düzeylerini saptamak amactyla Kocaeli sinırları içinde ikamet eden 600 kişiyle yüzyüze anket çalışması gerçekleştirilmiştir. Araştırma sonucunda, yurttaşların Kocaeli il ve ilçe belediyelerindeki eyönetişim hizmetlerine yönelik bilgi, farkındalık ve kullanım düzeylerinin düşük olduğu tespit edilmiş olup, sonuçlar bu eksende tartışılmıştır.
\end{abstract}

Keywords:

E-Governance,

Municipality,

Citizen,

Kocaeli,

\section{ÖZET}

E-Yönetişim, bilgi toplumuna geçiş süreci ve yeni iletişim teknolojilerinin gelişip yaygınlaşmasıyla kamu yönetim anlayışında yeni bir paradigma olarak karşımıza çımaktadır. Kamu politikalarının

\section{ABSTRACT}

With the transition to information society and the spread of new communication technologies, a new paradigm has emerged, which is defined as e-governance in public administration. While e-governance focuses on state-citizen interaction in designing, implementing and supervision of public policies, it provides positive gains for citizens and municipalities which are the most important representatives of public service provision at the local level. In order to develop and use e-governance practices in a way that will benefit the municipalities and citizens, the level of knowledge, awareness and usage of citizens should be determined. This study reflects a sectional part of the TUBITAK-117K012 project research which was conducted to examine the services provided by Kocaeli provincial and district municipalities in new media environments in terms of both municipalities and citizens within the framework of e-governance. In this research, 600 face-toface surveys were conducted to determine the level of knowledge, awareness and usage of citizens for the services provided by Kocaeli provincial and district municipalities in the context of e-governance in new media environments. Research findings show that the level of citizens' knowledge, awareness and use of egovernance services in Kocaeli province and district municipalities is low, and the results were discussed on this axis.

1 Bu çalışma, TÜBİTAK SOBAG tarafından desteklenen, 117K012 no'lu, "E-Yönetişim Bağlamında Yeni Medya Ortamlarında Belediye-Yurttaş Etkileşimi: Kocaeli İli Örneğì” başlıklı proje kapsamında, somut çıktıları paylaşmak amacı ile hazırlanmıştır. 


\section{GİRIŞ}

Bilgi ve iletişim teknolojilerinin gelişmesi toplumsal hayatın her alanında köklü değişikliklere yol açmış, bu gelişmelerin yarattığı dijital dönüşüm süreci, kamu ve özel sektörde iş yapma biçimlerini geliştiren ve kurumsal yetkinliği artıran yeni bir iş modeli ve yönetsel yaklaşım ortaya çıkarmıştır.

Dijitalleşme, kamu kurumlarının hizmet sunumunda dijital yönetişim ya da e-yönetişim olarak tanımlanan kapsamlı bir yönetim modelinin hızla yaygınlaşmasına neden olmuştur. Bilginin dijital ortama aktarılması suretiyle vatandaşların bilgi ve hizmetlere teknolojik araçlar vasıtasıyla doğrudan erişimini mümkün kılan eyönetişim, aynı zamanda kurumların yönetim yapısını ve yaklaşımını dönüştürmüş, devlet-vatandaş etkileşimini artırmış, karar alma süreçlerinde katılımcı, demokratik ve daha şeffaf bir yönetim anlayışının önünü açmıştır.

Kamu yönetiminde yeni bir paradigma olarak ele alınan e-yönetişim kavramının, "e-demokrasi" ve "e-devlet" olmak üzere iki temel kavram üzerinde yükseldiğini söylemek mümkündür. Yönetişim paradigmasının özü itibari ile bilgi toplumuna geçiş süreci ile kullanılmaya başlanan bu kavram, devlet-vatandaş ilişkilerini köklü biçimde değiştiren bir sisteme işaret etmekte, kamu kurumları ile paydaşlar arasında yeni iletişim teknolojileri sayesinde artan karşılıklı ilişkilere vurgu yapmaktadır.

E-yönetişim paradigmasının işlerlik kazanması ile birlikte, kamusal hizmet sunumunun yereldeki önemli temsilcilerinden olan belediyeler, e-yönetişim uygulamalarını iş süreçlerinde kullanarak kamu yönetiminin faaliyetlerini desteklemek ve geliştirmek için teknolojiden olabildiğince yararlanmakta, görev ve hizmetlerin elektronik iletişim ve işlem ortamlarında doğrudan, kaliteli, hızlı ve kesintisiz yürütülmesini sağlamakta; her kurum ve bireyin bilgi teknolojilerini kullanarak devletin sunduğu hizmetlere kolayca ulaşmasını amaçlamaktadır. Ayrıca, e-yönetişim uygulamaları, yurttaşlara işlemlerini kolay, hızlı, maliyetsiz bir biçimde gerçekleştirebilme; belediye temsilcileri ile etkileşimli ve anlık olarak iletişim kurabilme olanağı sağlamaktadır. Dolayısıyla yurttaşlar açısından sunulan hizmetlerden hızlı ve kolay biçimde yararlanma, şeffaf yönetim anlayışı çerçevesinde kentin geleceğini ilgilendiren konularda karar alma mekanizmasında yer alma olanağ gibi pek çok yarar söz konusudur.

Belediyelerin e-yönetişim uygulamalarının sağladığı tüm bu kazanımlar temelde belediye-yurttaş etkileşimine dayanmakla birlikte bu etkileşim sürecinin gerek belediyeler gerekse yurttaşlar tarafindan yeterince gerçekleştirilememesi/sağlanamaması sorun olarak karşımıza çıkmaktadır. Dolayısıyla belediyeler ve yurttaşlar açısından olumlu kazanımlar sağlayan e-yönetişim uygulamalarının her iki tarafa da fayda sağlayacak biçimde geliştirilip sürdürülmesine katkı sunmak amacıyla yurttaşlar tarafından bu uygulamalara yönelik bilgi, farkındalık ve kullanım düzeylerinin belirlenmesi gerekmektedir.

$\mathrm{Bu}$ araştırmada, Kocaeli il ve ilçe belediyelerinin e-yönetişim bağlamında yeni medya ortamlarında sundukları hizmetlere yönelik yurttaşların bilgi, farkındalık ve kullanım düzeylerini saptamak amaçlanmıştır. Bu amaçla, durum saptayıcı bir araştırma olarak planlanan bu çalışma, yurttaşların e-yönetişim hizmetlerine yönelik bilgi, farkındalık ve kullanım durumlarını Kocaeli ili üzerinden somutlaması açısından alana katkıda bulunmaktadır.

\section{KAVRAMSAL ÇERÇEVE}

Ekonomik, siyasal ve toplumsal aktörlerin işbirliği ve etkileşimi temelinde kamusal hizmetlerin etkin ve etkili sunumunu temel alan yönetişim, bilgi ve iletişim teknolojilerinin gelişmesi ve bu teknolojilerin kamu yönetim biçimlerini yakından etkilemesiyle dönüşüme uğramış ve e-yönetişim olarak önem kazanmaya başlamıştır.

E-yönetişim, kamu kurumları ile paydaş gruplar arasında yeni iletişim teknolojileri sayesinde artan karşıllklı ilişkileri vurgulamakta olup, kamu politikalarının oluşum ve sunum aşamalarının etkinlik ve kalitesini geliştirmeyi amaçlamaktadır (Gordon, 2012:5). Böylece e-yönetişim anlayışıyla yurttaşlara bilgi ve hizmetlere teknolojik araçlarla doğrudan ulaşım imkânı sağlanmakta, yurttaşlar kamusal işlerde hizmet edilen müşteri olarak değil, kamusal hizmetin üretiminde ortak olarak dikkate alınmaktadır.

E-yönetişim ile ilgili alanyazına bakıldığında farklı bakış açılarıyla kavramın ele alındığı görülmektedir. Bu bağlamda e-yönetişimi, bilgi ve iletişim teknolojileri temelli belediye-yurttaş etkileşimi bağlamında açıklayan görüşlerde; e- yönetişim, bilgi ve iletişim teknolojilerinin aktif kullanımı çerçevesinde kamu, yerel idare, vatandaşlar, sivil toplum kuruluşları ve özel sektör gibi paydaş gruplar arasında bilgi erişiminin etkin, şeffaf ve hesap verilebilir bir biçimde kullanımını sağlayan uygulamalar bütünü olarak ifade edilmektedir (Kanungo, 2004:409). E-yönetişime hizmet odaklı olarak yaklaşan diğer görüşlerde ise, e-yönetişim kamusal hizmetlerin 
düzenlenmesinde, sunumunda, vatandaşların bilgiye erişimlerinde, talep ve müracaatlarında, vergi - ceza bilgisi erişimi ve ödemelerinde, izin ve lisanslar ile ihalelerin arz edilmesinde elektronik araç kullanımını destekleyerek kamusal işlem maliyetlerinden büyük ölçüde tasarruf sağlayan verimli ve etkin bir yönetim tarzını ifade etmektedir (Demirel, 2010:71).

Devlet merkezli bir yönetim anlayışı yerine toplum merkezli bir yönetimi işler hale getirme stratejisi olarak tanımlanan e-yönetişimin (Ökmen vd, 2004:45) dört temel karakteristik özelliği bulunmaktadır (Riley, www.electronicgov.net 'ten akt.: Demirel, 2010:72):

- Elektronik Angajman (Sözleşme): Bilgilerin toplandığı zamanla, yayımlandığı zaman arasındaki cari uygulamaların giderek eskimesini, bu nedenle hızlı bir biçimde değişmesini anlatan çok çeşitli enformatik örnekleri içermektedir.

- Elektronik Danışma: Kamu görevlileriyle vatandaşlar ve baskı grupları arasındaki etkileşimi, iletişimi, kamu yönetimindeki halkla ilişkiler faaliyetlerini içermektedir.

- Elektronik Kontrolörlük (Denetçilik): Dönüşlü olarak bir ağın alt yapısı ve içeriğini yönetmek üzere ağ yapısı içinde konumlandırılmış, bütün bilişim ve telematik yazılımların tek bir sistemle karşılıklı bağlantı kurabilirliğini içermektedir.

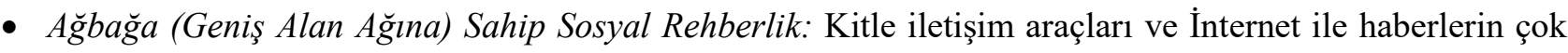
daha hızlı ve derinlemesine yayılmasını, toplumsal kuralları çiğneyenler hakkında halkın bilgilendirilmesini, bir anlamda halka sosyal rehberlik yapılmasını içermektedir.

E-yönetişim bilgi ve iletişim teknolojilerini merkeze aldığı için e-devlet politikalarına dayanan ağ temelli bir yönetişim sistemidir. Bu bağlamda bilinenin aksine, kamu kurumlarının bir web sayfası düzenleyerek İnternet üzerinden yayın yapmalarının çok ötesindedir (Özer, 2017:469). Yatay bir koordinasyon yapısıyla ilgili tüm tarafların ağ tipi örgütlenmeler içinde devlet yönetimine katılımını (Demirel, 2010:69-70), bilginin ve kurumlar arası iletişimin fiziki alandan sanal alana geçerek serbestçe yapılmasını, vatandaşların, özel şirketlerin ve çalışanların yararına olacak şekilde her türlü hizmete ulaşımın sağlanmasını öngören bir yapıdır. Bu yapıda bilgi ve iletişim teknolojilerinden yararlanmanın yanında, devletin vatandaşlara hizmet sunumundaki fonksiyonları ve süreçleri de bütünleştirilmekte, bir iş kültürü ve zihniyeti ortaya çıkarılmaktadır. Dolayısıyla e-yönetişim, yatay olarak yetki, kaynak ve görev aktarımının yapıldığı, toplumla bütünleşmiş biçimde devleti, sivil toplumu ve özel sektörü de kapsayan, bilgi ve iletişim teknolojilerince desteklenmektedir (Yereli vd., 2015:133-134).

E-yönetişim hizmetlerinin yerel düzeydeki en önemli uygulayıcıları arasında yer alan belediyeler de yeni medya teknolojilerini e-yönetişim kapsamındaki iş süreçlerinde kullanarak daha az maliyetle daha verimli bir çalışma olanağı elde etmektedir. Diğer taraftan yurttaşlar da e-yönetişim uygulamaları sayesinde, yeni teknolojiler yoluyla devletin her kurum ve kuruluşuna zaman ve mekân farkı gözetmeden ulaşabilmekte, taleplerini ifade edebilmekte, kendisine sunulan hizmetleri eleştirme imkânına kavuşarak politika oluşturma süreçleri içinde daha fazla yer almaktadır (Saraçbaşı, 2010:27). Dolayısıyla yurttaş açısından da sunulan hizmetlerden hızlı ve kolay biçimde yararlanma, şeffaf yönetim anlayışı çerçevesinde kentin geleceğini ilgilendiren müşterek faydalar için sesini duyurma ve karar alma mekanizmasında yer alma olană̆ gibi pek çok yararın söz konusu olduğu görülmektedir.

Belediyelerin yeni medya ortamlarındaki e-yönetişim hizmetleriyle ilgili alanyazına bakıldığında, dünyada ve ülkemizde bazı araştırmalar yapıldığı görülmektedir. Lethbridge (2015) Avrupa Birliği üyesi Almanya, Finlandinya, Danimarka, Estonya, İtalya, İngiltere, Fransa ve Hirvatistan'a yönelik olarak e-devlet uygulamalarını analiz ettiği çalışmasında, yerel ve bölgesel düzeyde hizmet sunumu açısından Almanya ve Danimarka'nın sayısal olarak en yüksek hizmet sağlayan ülkeler olduğunu tespit etmiştir. Aynı çalışma içerisinde Lethbridge (2015), İspanya'da Malaga Belediyesi'nin Şehir Konseyi İnnovasyon planını incelemiş ve bu çalışmanın Malaga belediyesinin daha iyi bir yönetişim kültürü oluşturmak amacı ile yapısal, işlevsel ve süreçsel bir gelişim planı içerdiğini ortaya koymuştur. Bu araştırmada, Finlandiya'da ise Utajärvi belediyesine yönelik olarak geliştirilen yeni yönetim modelini de inceleyen Lethbridge, politik konuların operasyonel hizmetlerden ayrılması ve yerel halkın elektronik bir geri bildirim sistemi ile istek ve düşüncelerini kolayca belediyeye iletebilmesi örneği üzerinde durmuştur. Yine aynı çalışma içerisinde İsveç'in Lomma kasabasında "belediye ile bağım" (my-municipalengagement) isimli 7/24 aktif bir uygulamanın hayata geçirilmesi üzerinde durmuştur. Bu uygulama su tüketimi, çocuk bakımı ve bina izinleri gibi 30'dan fazla e-hizmeti içermekte olup; hızlı ve güvenilir geniş ağ bağlantı sistemi ile İnternet tabanlı etkin bir yönetişim uygulaması olarak değerlendirilmiştir (Lethbridge, 2015:7-10). 
Uzak Doğu'da e-yönetişim çalışmaları incelendiğinde, Kore hükümeti Gıda, Tarım, Orman ve Balıkçılık Bakanlı̆̆ı'nın 10.02.2010-14.07.2010 tarihleri arasındaki Bakanlık Twitter hesabının incelendiği çalışma sonuçlarında Twitter'ın etkin bir bilgi dağıtım kanalı olmasının yanında sosyalleşme odaklı bir iletişim alanı olarak karşılıklı değiş tokuş işlevini yerine getiren sosyal medyanın yenilikçi bir iletişim aracı olduğu da belirlenmiştir. $\mathrm{Bu}$ alanda diğer bir örnek de, kamusal işlerini internet üzerinden gerçekleştiren Uzakdoğu ülkelerinin önde gelen devletlerinden Singapur'da 2000 y1lında nüfusun \%30'u gelir vergilerini yatırmak için çevrimiçi sistemi kullanmış ve bu uygulama Singapur devletine dosya basına işlem giderlerinde 2.7 Dolar tasarruf sağlamıştır (Durna ve Özel, 2008:24). 2008-2014 yılları arasında E-Devlet Gelişim İndeski (EGovernment Development Index) içerisinde ilk 10 ülke içerisinde yer alan Amerika Birleşik Devletleri'nde ise eyalet bazında e-devlet hizmetleri açısından Utah, New Jersey, North Carolina, Michigan ve Maine eyaletlerinin web sayfaları sundukları e-hizmetlere bağlı olarak e-belediyecilik alanında önemli örnekler olarak ön plana çıkmaktadır.

Türkiye'de ise yerel yönetimlerin e-yönetişim uygulamalarına bakıldığına, bu uygulamaların ilk olarak Yerelnet ve Yerelbilgi projeleri ile ortaya çıktığı görülmektedir. Yerel Yönetimler Bilgi Tabanı Projesi (YERELBİLGí Projesi) Türkiye'de yerel yönetimlerle ilgili tüm verilerin elektronik bir veri tabanı içerisinde toplanmasını ve karar alma mekanizmalarında bu verilerin analitik analizinin dahil olmasını amaçlayan bir çalışmadır. Yerelnet Projesi ise ülke düzeyinde özerk yerel yönetimlerin bilgi ve deneyim paylaşımını hedefleyen ortak bir bilgi havuzu olarak faaliyet göstermektedir (Güler, 2001:3; Nohutçu ve Demirel, 2005:46). Dolayısıyla yaşanan bu gelişmelere bağl1 olarak, Türkiye'de e-yönetişim hizmetlerine yönelik olarak çeşitli araştırmalar gerçekleştirilmiştir (Kaya Bengsir, 2000, 2002; Karaduman, 2004; Şahin, 2007; Doğu, 2008; Durna ve Özel, 2008; Kabakuş, 2010; Demirel, 2010; Özüpek, 2010; Çavuş, 2011; Tanyıldızı ve Karatepe, 2011; Sobacı ve Altınok, 2011; Negiz, 2011; Tarhan, 2012; Serenli, 2013; Kabakuş, 2014; Bilgili, 2015; Zeren vd., 2015; Şat, 2016).

\section{ARAŞTIRMANIN YÖNTEMI}

Kocaeli il ve ilçe belediyelerinin e-yönetişim bağlamında yeni medya ortamlarında sundukları hizmetlere yönelik yurttaşların bilgi, farkındalık ve kullanım düzeylerini saptamak amacıyla tanımlayıcı/durum saptayıcı bir araştırma modeli kullanılan bu çalışmada, kantitatif (nicel) araştırma yöntemiden yararlanılmıştır.Kantitatif araştırma yönteminde, önceden hazırlanmış bir soru formuna bağlı kalınarak, sayısal yorum ve genelleme yapılabilmekte, araştırılan konuya ilişkin, evreni temsil edecek örneklemin araştırma konusu hakkındaki fikrinin yönü sorgulanmaktadır (Yıldırım ve Şimşek, 2006).

Bu bağlamda, araştırma evrenini Kocaeli ili coğrafi sınırları içinde bulunan (Kocaeli Büyükşehir Belediyesi ve 12 ilçe belediyelerinin hizmet ve sorumluluk alanında bulunan) hanelerde yaşayan 18 yaş ve üzeri Türkiye Cumhuriyeti vatandaşları oluşturmaktadır. Araştırmada yurttaş değişkeni için örneklem, Türkiye İstatistik Kurumu'ndan sağlanan adrese dayalı nüfus veri tabanından olasılıklı basit tesadüfi örnekleme yoluyla seçilerek belirlenmiş ve her ilçe, nüfusu bakımından ağırlık oranına göre örneklemde temsil edilmiştir. Bu bağlamda Kocaeli il sınırları içerisinde yaşayan 18 yaş ve üzeri seçmen niteliği taşıyan 1.221 .771 kişi araştırmanın evrenini oluşturmaktadır (www.ysk.gov.tr). Araştırmalarda sıkça kullanılan örneklem belirleme kaynaklarından olan Survey System'e ve Hsia (1988), Sue \& Ritter (2012), Backstrom \& Hursh (1981) göre ilgili birim sayıs1 100.000 'in üzerinde olan evren üzerinden $\% 95$ güvenilirlik düzeyi ve kabul edilebilir hata pay1 \%4 olmak üzere, araştırmanın konusuna uygun olarak örneklem İnternet erişimi ve kullanımı olan 600 birim olarak belirlenmiştir. Araştırmada niceliksel analize uygun, kesitsel ve durum saptayıcı özellikte bir yaklaşım olan anket (survey) tipi veri toplama tekniği benimsenmiştir.

Yüz yüze anket tekniği kullanılan bu araştırmada, soru formunun hazırlanmasında, Rutgers Üniversitesi-Newark E-Yönetişim Enstitüsü'nün "Dünya Belediyelerinde Dijital Yönetişim” başlıklı araştırmasının ölçeği ile Chen ve Gant (2001), Şahin (2007), Çoruh (2009)'ın araştırma bulgularından yararlanılarak yeni bir ölçek oluşturulmuştur.

Toplamda 5 bölümden oluşan anket formunun birinci bölümünde demografik bilgiler yer almakta olup; katılımcılardan yaş, cinsiyet, eğitim durumu, medeni durumu, çalışma durumu, meslek değişkenlerine ilişkin sorulara yanıt vermeleri istenmiştir. İnternet ve sosyal ağ kullanım durumunu ölçen anket formunun ikinci bölümünde; İnternetin kullanım sıklığı, İnternete erişilen araçların türü, teknolojik araç sahipliği, İnternet kullanma amaçları, sosyal medya kullanım durumu, sosyal ağlara yönelik hesap bilgisi gibi değişkenler incelenmiştir. Anket formunun üçüncü bölümünde yurttaşların belediyelerin e-yönetişim bağlamında çevrimiçi 
uygulamalarını içerik, kullanılabilirlik, gizlilik/güvenlik, yurttaş ve sosyal etkileşim özellikleri bağlamında kullanım durumları incelenmiştir. Formun dördüncü bölümü, yurttaşların e-belediyecilik hizmetleriyle ilgili dijital kullanım becerilerini ölçme amacı taşımaktadır. Bu bölümde ayrıca dijital beceri sınıflandırması dahilinde katılımcıların operasyonel, formel, enformasyonel ve stratejik dijital beceri düzeylerini ölçmeye yönelik sorularda yer almaktadır.Anket formunun beşinci bölümünde ise, yeni medya ortamlarında katılımcılık ve belediye-yurttaş etkileşiminin incelenmesi amaciyla belediye hizmetlerinden bilgi isteme durumu, dezavantajlı gruplara yönelik hizmet sunumu, belediye başkanı ile iletişim kurma durumları, iletişime geçilen konu türü ile sosyal medya aracı, geri bildirim durumu ve süresi gibi değişkenlere ilişkin sorular yer almaktadır. Ayrıca bu bölümde dijital beceri sınıflandırması dahilinde katılımcıların içerik yaratma ve dijital beceri düzeylerini ölçmeye yönelik sorulara da yer verilmiştir. Bu çalışma, amaçları doğrultusunda, anket formunun 1'inci ve 3’üncü bölümleri ile sınırlandırılmıştır.

Anket görüşmeleri 5 Aralık 2017- 1 Şubat 2018 tarihleri arasında TÜİK'den alınan adrese dayalı hane halkı verileri doğrultusunda katılımcıların bulundukları hanelerde ve/veya muhtarlık binalarında gerçekleştirilmiş olup, elde edilen veriler SPSS programı aracılığıyla analiz edilip yorumlanmıştır.

\section{ARASTTIRMADAN ELDE EDILEN VERILERİN ANALIZİ}

Kocaeli il ve ilçe belediyelerinin e-yönetişim bağlamında yeni medya ortamlarında sundukları hizmetlere yönelik yurttaşların bilgi, farkındalık ve kullanım düzeylerini saptamak amacıyla gerçekleştirilen araştırmaya yönelik elde edilen veriler aşağıdaki gibidir:

\subsection{Demografik Özellikler}

Ankete katılan yurttaşların demografik özelliklerine bakıldığında; \%37,2'si 36-50 yaş aralığında, \%26'sının 26-35 yaş aralığında olduğu görülmektedir. Bu katılımcıların \%63'ü erkek, \%37'si kadın olup,\%68,5'i evlidir. Katılımcıların öğrenim ve çalışma durumlarına baktığımızda ise \%40,4'ının orta öğretim mezunu olduğu ve \%72,2'sinin ise çalıştığı/kendi işini yaptığı görülmektedir.

\subsection{Yurttaşların E-Yönetişim Bağlamındaki Çevrimiçi Uygulamalara Yönelik Bilgi ve Kullanım Durumu}

Yurttaşların belediyelerin sunduğu e-yönetişim bağlamındaki çevrimiçi uygulamalarına yönelik bilgi ve kullanım durumlarına ilişkin veriler aşağıdaki gibidir:

\subsubsection{Yurttaşların Belediyelerle İletişime Geçme Durumları ve Kanalları}

Tablo1. Yurttaşların Yürütülen Hizmetlerle İlgili Olarak Belediyelerle İletişime Geçme Durumlarının Analizi

\begin{tabular}{|l|c|c|}
\hline & $\mathrm{N}$ & $(\%)$ \\
\hline Evet & 201 & 33,5 \\
Hayır & 331 & 55,2 \\
Kismen & 68 & 11,3 \\
Soruyu Cevaplayan Kat1limcilar & 600 & 100 \\
Soruyu Cevaplamayan Kat1limcilar & 0 & 0 \\
Toplam & 600 & 100 \\
\hline
\end{tabular}

Kaynak: Yazarlar tarafından hazırlanmıştır.

Tablo1'de görüldüğü üzere, katılımcıların yürtülen hizmetlerle ilgili belediyelerle iletişime geçme durumlarını analiz eden bu soruya, katılımcıların $\% 33,5$ 'i belediyelerle yürüttükleri faaliyetlerle bağlantılı olarak iletişime geçtiğini; \%11,3'ü kısmen iletişime geçtiğini, \%55,2'si iletişime geçmediğini belirtmiştir. Bu bağlamda katılımcıların çoğunun yürütülen hizmetler doğrultusunda belediyelerle iletişim kurmadıkları söylenebilmektedir. 
Tablo 2. Yurttaşların Belediyelerle Yürüttükleri Hizmetlerle İlintili Olarak İletişime Geçme Kanallarının Analizi

\begin{tabular}{|c|c|c|c|c|c|c|c|c|c|c|c|c|}
\hline \multirow{2}{*}{ Sıra } & \multicolumn{2}{|c|}{ İnternet } & \multicolumn{2}{c|}{$\begin{array}{c}\text { Yüz yüze } \\
\text { Görüşme }\end{array}$} & \multicolumn{2}{|c|}{ Telefon } & \multicolumn{2}{|c|}{ Faks } & \multicolumn{2}{c|}{$\begin{array}{c}\text { Mobil } \\
\text { Uygulamalar }\end{array}$} & \multicolumn{2}{c|}{ Diğer } \\
\cline { 2 - 13 } & $\mathbf{N}$ & $\mathbf{\%}$ & $\mathbf{N}$ & $\mathbf{\%}$ & $\mathbf{N}$ & $\mathbf{\%}$ & $\mathbf{N}$ & $\mathbf{\%}$ & $\mathbf{N}$ & $\mathbf{\%}$ & $\mathbf{N}$ & $\mathbf{\%}$ \\
\hline 1 & 53 & 52 & 26 & 25,5 & 23 & 22,6 & 0 & 0 & 0 & 0 & 0 & 0 \\
\hline 2 & 101 & 60,5 & 55 & 32,9 & 11 & 6,6 & 0 & 0 & 0 & 0 & 0 & 0 \\
\hline 3 & 97 & 62,2 & 49 & 31,4 & 9 & 5,8 & 1 & 0,6 & 0 & 0 & 0 & 0 \\
\hline 4 & 3 & 37,5 & 1 & 12,5 & 2 & 25 & 2 & 25 & 0 & 0 & 0 & 0 \\
\hline
\end{tabular}

Kaynak: Yazarlar tarafından hazırlanmıştır.

Belediyelerle iletişim kuran katılımcıların en çok hangi araçları kullandıklarını sıralamaları istendiğinde, Tablo 2'de görüldügü üzere katılımcılar ilk sirada $\% 52^{\prime}$ lik oranla internet, $\% 25,5^{\prime}$ lik oranla yüz yüze görüşme, $\% 22,6$ 'lık oranla telefon ile iletişim kurmaktadır. Ayrıca, araştırma verilerine göre ankete katılan yurttaşların tamamı mobil uygulamalar ve diğer kanallar aracılığı ile belediyelerle iletişime geçmediğini ifade etmiştir.

\subsubsection{Yurttaşların E-Belediyecilik Uygulamalarına Yönelik Bilgi Düzeyleri}

Tablo 3. Yurttaşların E-Belediyecilik Uygulamalarına Yönelik Bilgi Düzeylerinin Analizi

\begin{tabular}{|l|c|c|}
\hline & $\mathrm{N}$ & $(\%)$ \\
\hline Evet & 136 & 22,7 \\
Hayır & 436 & 72,6 \\
Kismen & 28 & 4,7 \\
Soruyu Cevaplayan Kat1limcilar & 600 & 100 \\
Soruyu Cevaplamayan Katılımcilar & 0 & 0 \\
Toplam & 600 & 100 \\
\hline
\end{tabular}

Kaynak: Yazarlar tarafından hazırlanmıştır.

Tablo 3'de görüldüğü üzere katılımcıların e-belediyecilik uygulamalarına yönelik bilgi sahibi olma durumlarını analiz eden bu soru, toplam katılımcıların tamamı tarafından cevaplanmış olup, yurttaşların \%22,7'si ebelediyecilik hizmetleri hakkında bilgi sahibi olduklarını; \%4,7'si kısmen bilgi sahibi olduklarını,\%72,6'sı bilgi sahibi olmadıklarını belirtmiştir. Bu bağlamda ankete katılan yurttaşların e-belediyecilik uygulamaları ile ilgili bilgi sahibi olmadıkları söylenebilmektedir.

Tablo 4. Yurttaşların E-Belediyecilik Uygulamalarından Haberdar Oldukları Kaynakların Analizi

\begin{tabular}{|l|c|c|c|}
\hline & $\mathrm{N}$ & Genel $(\%)$ & Geçerli (\%) \\
\hline Televizyon & 2 & 0,3 & 1,2 \\
Gazete & 6 & 1 & 3,7 \\
Radyo & 2 & 0,3 & 1,2 \\
Açıkhava reklamları & 10 & 1,7 & 6,1 \\
Dergiler & 3 & 0,5 & 1,8 \\
İnternet & 29 & 4,8 & 17,7 \\
Sosyal medya & 13 & 2,2 & 7,9 \\
Yakın çevre & 46 & 7,7 & 28 \\
Belediyelerin web sitesi & 49 & 8,2 & 29,9 \\
Diğer & 4 & 0,7 & 2,4 \\
Soruyu Cevaplayan Katılımcılar & 164 & 27,4 & 100 \\
Soruyu Cevaplamayan Katılımcılar & 436 & 72,6 & 0 \\
Toplam & 600 & 100 & - \\
\hline
\end{tabular}

Kaynak: Yazarlar tarafından hazırlanmıştır.

Tablo 4'de görüldüğü üzere, e-belediyecilik uygulamaları ile ilgili bilgi sahibi olan yurttaşların e-belediyecilik hizmetlerinden nasıl haberdar olduklarını ölçme amacı taşıan bu soru bağlamında katılımcılar bilgi edinme kaynakları olarak \%29,9'luk oranla belediyelerin web sitesini, \%28'lik oranla yakın çevrelerini, \%17,7'lik oranla İnternet'i, \%7,9'luk oranla sosyal medyayı, \%6,1'lik oranla açık hava reklamlarını, \%3,7'lik oranla gazeteleri, \%1,8'lik oranla dergileri, \%0,2'lük oranlarla televizyon ve radyoyu göstermişlerdir. Diğer kategorisinde yer alan kaynakların oranı ise \%2,4'tür. Bu bağlamda ankete katılan yurttaşların e-belediyecilik hizmetlerinden daha çok belediyelerin web sitesi ve yakın çevreleri vasıtasıyla haberdar oldukları söylenebilmektedir. 


\subsubsection{Yurttaşların E-Belediyecilik Uygulamalarına Yönelik Kullanım Durumları}

Tablo 5. Yurttaşların E-Belediyecilik Kullanım Durumlarının Analizi

\begin{tabular}{|l|c|c|}
\hline & $\mathrm{N}$ & $(\%)$ \\
\hline Evet & 64 & 10,7 \\
Hayir & 536 & 89,3 \\
Toplam & 600 & 100 \\
\hline
\end{tabular}

Kaynak: Yazarlar tarafından hazırlanmıştır.

Tablo 5'de görüldüğü üzere ankete katılan yurttaşların tamamı e-belediyecilik kullanım durumlarını ölçen bu soruya cevap vermiş olmakla birlikte, katılımcıların \%10,7'si e-belediyecilik hizmetlerini daha önce kullandığını belirtirken; \%89,3'ü bu hizmetleri daha önce kullanmadığını ifade etmiştir. Tablo 5'de elde edilen veriler, Tablo 3'de yer alan veriler ile bir arada değerlendirildiğinde; Kocaeli ili genelinde ikamet eden yurttaşların e-belediyecilik hizmetlerinden haberdar olma durumu ile kullanım durumları arasında farklar olduğu sonucuna ulaşılmaktadır. Bu bağlamda, araştırma verilerine bağlı olarak yurttaşların bir kısmının ebelediyecilik hizmetlerinden kısmen ya da tamamen haberdar olmalarına rağmen, bu hizmetleri daha önce kullanmadığı sonucu ortaya çıkmaktadır.

Tablo 6. Yurttaşların E-Belediyecilik Hizmetlerini Kullanmama Nedenlerinin Analizi

\begin{tabular}{|c|c|c|c|}
\hline & $\mathrm{N}$ & Genel (\%) & Geçerli (\%) \\
\hline Bu hizmetleri kullanacak bilgisayar bilgisine hakim değilim & 59 & 5,9 & 11 \\
\hline Bu hizmetleri kullanacak teknolojik araca sahip değilim & 19 & 1,9 & 3,5 \\
\hline Belediye ve yetkilileriyle İnternette iletişime geçme ihtiyacım olmuyor & 240 & 24,1 & 44,8 \\
\hline İlgili web siteleri ve İnternet hizmetlerinin varlığından haberdar değilim & 204 & 20,5 & 38,1 \\
\hline Belediye hizmetlerini karşılamak için İnternet kullanmaya ihtiyacım olmuyor & 180 & 18,1 & 33,6 \\
\hline İnternet hizmetlerine güvenmiyorum & 110 & 11 & 20,5 \\
\hline İnternet hizmetini kullanmayı denedim ancak sistemi kullanım açısından çok zor buluyorum & 16 & 1,6 & 3 \\
\hline İstediğim/ihtiyaç duyduğum hizmeti karşılamak için İnternet kullanmak istemiyorum & 73 & 7,3 & 13,6 \\
\hline İstediğim konuyla ilgili hizmet içeriği ve alt yapısı yeterli değil & 20 & 2 & 3,7 \\
\hline Neden kullanmadığımı bilmiyorum/fikrim yok & 69 & 6,9 & 12,9 \\
\hline Diğer & 7 & 0,7 & 1,3 \\
\hline Soruyu Cevaplayan Katılımcilar & 536 & 89,3 & 100 \\
\hline Soruyu Cevaplamayan Katılımcılar & 64 & 10,7 & 0 \\
\hline Toplam & 600 & 100 & - \\
\hline
\end{tabular}

Kaynak: Yazarlar tarafından hazırlanmıştır.

Tablo 6'da görüldüğü üzere yurttaşların e-belediyecilik hizmetlerini kullanmama nedenlerini ölçme amacı taşıyan bu soru; katılımcıların e-belediyecilik hizmetlerini kullanmama nedenlerini çoklu olarak analiz edebilecek bir biçimde tasarlanmış olup, araştırma verilerine bağlı olarak e-belediyecilik hizmetlerini kullanmadığını ifade eden katılımcıların kullanmama nedenleri daha çok \%44,8'lik oranla yurttaşların Belediye ve yetkilileriyle İnternette iletişime geçme ihtiyac1 olmaması, \%38,1'lik oranla ilgili web siteleri ve İnternet hizmetlerinin varlığından haberdar olmaması, \%33,6'lı oranla belediye hizmetlerini karşılamak için İnternet kullanmaya ihtiyaç duymaması, \%20,5'lik oranla İnternet hizmetlerine güven duymaması şeklinde karşımıza çıkmaktadır.

Tablo 7. Yurttaşların Belediye Bazlı E-belediyecilik Hizmetlerinden Yararlanma Durumlarının Analizi

\begin{tabular}{|l|c|c|c|}
\hline & N & Genel (\%) & Geçerli (\%) \\
\hline Kocaeli Büyükşehir Belediyesi & 19 & 3,2 & 29,7 \\
Bağlı olunan ilçe belediyesi & 45 & 7,5 & 70,3 \\
Soruyu Cevaplayan Katılımcılar & 64 & 10,7 & 100 \\
Soruyu Cevaplamayan Katılımcılar & 536 & 89,3 & 0 \\
Toplam & 600 & 100 & - \\
\hline
\end{tabular}

Kaynak: Yazarlar tarafından hazırlanmıştır.

Tablo 7'de görüldüğü üzere ankete katılan yurttaşların e-belediyecilik hizmetlerinden yararlanma durumlarını il ve ilçe belediyeleri bazında ölçme amacı taşıyan bu soru bağlamında, e-belediyecilik hizmetlerini kullandıklarını ifade eden katılımcıların \%29,7'sinin bu hizmetleri Kocaeli Büyükşehir Belediyesi aracılığı ile gerçekleştirdiği; \% 70,3'ünün bağlı oldukları ilçe belediyesi aracılığı ile gerçekleştirdiği bulgularına ulaşılmıştır. 
Tablo 8. Yurttaşların E-Belediyecilik Hizmetlerini Kullanma Nedenlerinin Analizi

\begin{tabular}{|l|c|c|c|}
\hline & $\mathrm{N}$ & Genel (\%) & Geçerli (\%) \\
\hline Kullanım kolaylı̆̆ı & 59 & 30,9 & 92,2 \\
Hizmet çeşitliliğinin fazla olması & 23 & 12 & 35,9 \\
Daha hızlı hizmet sağlaması & 43 & 22,5 & 67,2 \\
Daha güvenilir olması & 24 & 12,6 & 37,5 \\
Etkileşime daha açık bir yapıya sahip olması & 20 & 10,5 & 31,3 \\
İçerik anlamında daha fazla bilgiye yer vermesi & 21 & 11 & 32,8 \\
Diğer & 1 & 0,5 & 1,6 \\
Soruyu Cevaplayan Katılımcılar & 64 & 10,7 & 100 \\
Soruyu Cevaplamayan Katılımcılar & 536 & 89,3 & 0 \\
Toplam & 600 & 100 & - \\
\hline
\end{tabular}

Kaynak: Yazarlar tarafından hazırlanmıştır.

Tablo 8'de görüldügü üzere yurttaşların e-belediyecilik hizmetlerini kullanma nedenlerini ölçme amacı taşıyan bu soru; katılımcıların e-belediyecilik hizmetlerini kullanım nedenlerini çoklu olarak analiz edebilecek bir biçimde tasarlanmış olup, araştırma verilerine bağlı olarak e-belediyecilik hizmetlerini kullandığını belirten katılımcıların bu hizmetleri kullanım nedenleri; \%92,2'lik oranla kullanım kolaylığı, \%67,2'lik oranla daha hızlı hizmet sağlanması, \%37,5'lik oranla daha güvenilir olması, \%35,9'luk oranla hizmet çeşitliliğinin fazla olması, $\% 32,8$ 'lik oranla içerik olarak daha fazla bilgiye yer verilmesi, $\% 31,3$ 'lük oranla etkileşime daha açı bir yapıya sahip olması ve \%1,6'l1k oranla diğer nedenler olarak karşımıza çıkmaktadır. Bu bağlamda ankete katılan yurttaşların e-belediyecilik hizmetlerini daha çok kullanımının kolay olması ve hızlı hizmet sağlanması gerekçeleriyle kullandıkları söylenebilmekle birlikte, bu hizmetlerin güvenilir olması ve hizmet çeşitliliği hususunda fazla katılım göstermedikleri görülmektedir. Dolayısıyla yurttaşların e-belediyecilik hizmetlerinin güvenilir olması ve hizmet çeşitliliği ile ilgili yeterli bilgiye sahip olmadıkları ve/veya bu hizmetleri güvenilir ve çeşitli bulmadıkları ve/veya bu hizmetlerin güvenilir ve çeşitli olması/olmamasının bu hizmetleri kullanmak için tercih sebebi olarak yeterli öneme sahip olmadığı söylenebilmektedir.

Tablo 9. Yurttaşların E-Belediyecilik Kullanım Alışkanlıklarının Analizi

\begin{tabular}{|l|c|c|c|}
\hline & $\mathrm{N}$ & Genel (\%) & Geçerli (\%) \\
\hline Internet üzerinde yapılabilen tüm işlemleri, e-belediyecilikle yapıyorum & 12 & 2,0 & 18,8 \\
İnternet üzerinde yapılabilen bazı işlemleri, e-belediyecilikle yapıyorum & 52 & 8,7 & 81,2 \\
Soruyu Cevaplayan Katılımcılar & 64 & 10,7 & 100 \\
Soruyu Cevaplamayan Katılımcılar & 536 & 89,3 & 0 \\
Toplam & 600 & 100 & - \\
\hline
\end{tabular}

Kaynak: Yazarlar tarafından hazırlanmıştır.

Tablo 9'da görüldüğü üzere ankete katılan yurttaşların e-belediyecilik hizmetlerini kullanım alışkanlıklarını ölçme amacı taşıyan bu soruya verilen yanattlar değerlendirildiğinde, e-belediyecilik hizmetlerini kullandıklarını ifade eden katılımcıların \%18,8'inin İnternet üzerinde yapılabilen tüm işlemleri e-belediyecilik uygulamaları ile gerçekleştirdiği; \%81,2'si İnternet üzerinde yapılabilen vergi ödeme, istek ve talepte bulunma, şikayette bulunma, herhangi bir hizmet alanında izin başvurusu yapma gibi bazı işlemleri, e-belediyecilik uygulamaları aracılığı ile gerçekleştirdiği verilerine ulaşılmıştır. 
Tablo 10. Yurttaşların Hizmet Alanlarına Yönelik E-Belediyecilik Kullanım Durumlarının Analizi

\begin{tabular}{|l|c|c|c|}
\hline & $\mathrm{N}$ & Genel (\%) & Geçerli (\%) \\
\hline Ulaşım & 37 & 11,8 & 57,8 \\
Kültür ve sanat & 21 & 6,7 & 32,8 \\
Meslek ve beceri kazanma & 12 & 3,8 & 18,8 \\
Su ve kanalizasyon & 15 & 4,8 & 23,4 \\
Hizmet karş1lğı alınacak ücretler ve cezalar & 31 & 9,9 & 48,4 \\
Sosyal hizmetler ve yardım & 15 & 4,8 & 23,4 \\
Çevre düzenlemesi ve korunması & 17 & 5,4 & 26,6 \\
Temizlik ve katı atık & 18 & 5,8 & 28,1 \\
Dinlenme/Eğlence & 8 & 2,6 & 12,5 \\
Sağlık hizmetleri & 15 & 4,8 & 23,4 \\
Kamu güvenliği & 10 & 3,2 & 15,6 \\
Arama ve kurtarma hizmetleri & 3 & 1 & 4,7 \\
Turizm ve tanıtım & 7 & 2,2 & 10,9 \\
Konut edinme, imar ve istimlak & 26 & 8,3 & 40,6 \\
Coğrafi ve kent bilgi sistemleri & 12 & 3,8 & 18,8 \\
Defin ve mezarlıklar & 7 & 2,2 & 10,9 \\
İtfaiye & 5 & 1,6 & 7,8 \\
İstihdam ve gelir hizmetleri & 7 & 2,2 & 10,9 \\
Nikah hizmetleri & 4 & 1,3 & 6,3 \\
Gerçek ve tüzel kişiler için izin ve ruhsatlar & 16 & 5,1 & 25 \\
Spor & 7 & 2,2 & 10,9 \\
Diğer & 20 & 6,4 & 31,3 \\
Soruyu Cevaplayan Katılımcılar & 64 & 10,7 & 100 \\
Soruyu Cevaplamayan Katılımcılar & 536 & 89,3 & - \\
Toplam & 600 & 100 & - \\
\hline
\end{tabular}

Kaynak: Yazarlar tarafından hazırlanmıştır.

Tablo 10'da görüldüğü üzere ankete katılan yurttaşların hizmet alanları bazında e-belediyecilik hizmetlerini kullanım durumlarını ölçme amacı taşıyan bu soru, katılımcıların e-belediyecilik hizmetlerini kullanım alanlarını çoklu olarak analiz edebilecek bir biçimde tasarlanmıştır. Bu bağlamda, araştırma verilerine bağlı olarak e-belediyecilik hizmetlerini kullandığını belirten katılımcıların bu hizmetleri kullanım alanları daha çok $\% 57,8^{\prime}$ 'lik oranla ulaşım; \%48,4'lik oranla hizmet karşılığ 1 alınacak ücret ve cezalar, \%40,6'lık oranla konut edinme, imar ve istimlak, \%32,8'lik oranla kültür-sanat olarak karşımıza çıkmaktadır.

Tablo 11. Yurttaşların E-Belediyecilik Hizmetleri İle İlgili Memnuniyet Düzeylerinin Analizi

\begin{tabular}{|l|c|c|c|}
\hline & $\mathrm{N}$ & Genel (\%) & Geçerli (\%) \\
\hline Çok memnunum & 8 & 1,3 & 12,5 \\
Memnunum & 39 & 6,5 & 60,9 \\
Kararsızım & 7 & 1,2 & 10,9 \\
Memnun değilim & 9 & 1,5 & 14,1 \\
Hiç memnun değilim & 1 & 0,2 & 1,6 \\
Soruyu Cevaplayan Katılımcılar & 64 & 10,7 & 100 \\
Soruyu Cevaplamayan Katılımcılar & 536 & 89,3 & 0 \\
Toplam & 600 & 100 & - \\
\hline
\end{tabular}

Kaynak: Yazarlar tarafından hazırlanmıştır.

Tablo 11'de görüldüğü üzere ankete katılan yurttaşların e-belediyecilik hizmetlerine yönelik memnuniyet düzeylerini ölçme amacı taşıyan ve 5'li likert ölçeği kullanılarak tasarlanan bu soru bağlamında, e-belediyecilik hizmetlerini kullandıklarını ifade eden katılımcıların \%12,5'inin e-belediyecilik hizmetlerinden çok memnun olduğu, \%60,9'unun memnun olduğu, \%10,9'unun hizmetleri değerlendirme noktasında kararsız olduğu, \%14,1'inin memnun olmadığı, \%1,6'sının ise hiç memnun olmadığına yönelik bulgulara ulaşılmıştır.

Tablo 12. Yurttaşların E-Belediyecilik Hizmetleri İle ilgili Geri Bildirim Alma Durumlarının Analizi

\begin{tabular}{|l|c|c|c|}
\hline & $\mathrm{N}$ & Genel (\%) & Geçerli (\%) \\
\hline Evet & 34 & 5,7 & 53,1 \\
Hayır & 24 & 4 & 37,5 \\
Kısmen & 6 & 1 & 9,4 \\
Soruyu Cevaplayan Katılımcılar & 64 & 10,7 & 100 \\
Soruyu Cevaplamayan Katılımcılar & 536 & 89,3 & 0 \\
Toplam & 600 & 100 & - \\
\hline
\end{tabular}

Kaynak: Yazarlar tarafından hazırlanmıştır. 
Tablo 12'de görüldüğü üzere, katılımcıların e-belediyecilik hizmetleri ile ilgili geri bildirim alma düzeylerini ölçmeyi amaçlayan bu soru bağlamında, e-belediyecilik hizmetlerini kullandıklarını ifade eden anket katılımcılarının \%53,1'inin gerçekleştirdikleri hizmetlerle ilgili geri bildirim aldığ $1, \% 37,5$ 'inin almadığ 1 ve \%9,4'ünün kısmen aldığına yönelik bulgulara ulaşılmıştır. Bu bağlamda e-yönetişim paradigması için önemli olan belediye-yurttaş etkileşiminin sağlanmasında ankete katılan ve e-belediyecilik kullananan yurttaşların çoğunun geri bildirim aldıkları söylenebilmektedir.

Tablo 13. Yurttaşların E-Belediyecilik Hizmetleri İle ilgili Yaptıkları İşlemlere Geri Bildirim Alma Sürelerinin Analizi

\begin{tabular}{|l|c|c|c|}
\hline & $\mathrm{N}$ & Genel (\%) & Geçerli (\%) \\
\hline Aynı gün içerisinde & 9 & 1,5 & 22,5 \\
1 gün sonra & 4 & 0,7 & 10 \\
1 hafta içerisinde & 20 & 3,3 & 50 \\
1 ay içerisinde & 7 & 1,2 & 17,5 \\
Diğer & 0 & 0 & - \\
Soruyu Cevaplayan Katılımcilar & 40 & 6,7 & 0 \\
Soruyu Cevaplamayan Katılımcilar & 560 & 93,3 & - \\
Toplam & 600 & 100 & \\
\hline
\end{tabular}

Kaynak: Yazarlar tarafından hazırlanmıştır.

Tablo 13'de görüldüğü üzere ankete katılan yurttaşların e-belediyecilik hizmetleri ile ilgili yaptıkları işlemlere geri bildirim alma sürelerini analiz etmeyi amaçlayan bu soruya, katılımcıların çoğu \%50 oranla bir hafta içerisinde, \%22,5 oranla aynı gün içerisinde ve \%17,5 oranla 1 ay içerisinde geri bildirim aldıkları cevaplarını vermiştir. Bu bağlamda ankete katılan yurttaşların e-belediyecilik hizmetleri ile ilgili yaptıkları işlemlere genellikle bir hafta içerisinde geri bildirim aldıkları söylenebilmektedir.

Tablo 14. Yurttaşların E-Belediyecilik Uygulamalarıyla İlgili Bilgi Düzeylerinin ve Bu Hizmetlerin Varlığının EBelediyecilik Uygulamalarına Yönelik Tutumlarına Etkisinin Analizi

\begin{tabular}{|c|c|c|c|c|c|c|c|c|c|c|c|c|c|c|c|}
\hline & \multicolumn{2}{|c|}{$\begin{array}{l}\text { Soruyu } \\
\text { Cevaplayan } \\
\text { Katılımcilar }\end{array}$} & \multirow{2}{*}{$\begin{array}{l}\text { Ort. } \\
\end{array}$} & \multicolumn{3}{|c|}{ Evet } & \multicolumn{3}{|c|}{ Hayır } & \multicolumn{3}{|c|}{ Kismen } & \multicolumn{3}{|c|}{ Fikrim/ Bilgim Yok } \\
\hline & $\mathrm{N}$ & $\%$ & & $\mathrm{~N}$ & $\begin{array}{c}\mathrm{G} \\
(\%)\end{array}$ & $\begin{array}{l}\text { Gçr } \\
(\%)\end{array}$ & $\mathrm{N}$ & $\begin{array}{c}\mathrm{G} \\
(\%)\end{array}$ & $\begin{array}{l}\text { Gçr } \\
(\%)\end{array}$ & $\mathrm{N}$ & $\begin{array}{c}\mathrm{G} \\
(\%)\end{array}$ & $\begin{array}{l}\text { Gçr } \\
(\%)\end{array}$ & $\mathrm{N}$ & $\begin{array}{c}\mathrm{G} \\
(\%)\end{array}$ & $\begin{array}{l}\text { Gçr } \\
(\%)\end{array}$ \\
\hline $\begin{array}{l}\text { Bağlı olduğum belediyenin web sitesinde } \\
\text { herhangi bir hizmet alanında izin } \\
\text { başvurusu yapılabilmektedir. }\end{array}$ & 64 & 10,7 & 3,05 & 16 & 2,7 & 25 & 6 & 1 & 9,4 & 1 & 0,2 & 1,6 & 41 & 6,8 & 64,1 \\
\hline $\begin{array}{l}\text { Bağlı olduğum belediyenin web sitesinde } \\
\text { herhangi bir konuda izin almaya yönelik } \\
\text { başvuru yapilabilmesi } \\
\text { etmemde etkilidir. }\end{array}$ & 64 & 10,7 & 1,48 & 49 & 8,2 & 76,6 & 6 & 1 & 9,4 & 2 & 0,3 & 3,1 & 7 & 1,2 & 10,9 \\
\hline $\begin{array}{l}\text { Bağlı olduğum belediyenin web sitesinde } \\
\text { işlem takip sistemi bulunmaktadır. }\end{array}$ & 64 & 10,7 & 2 & 35 & 5,8 & 54,7 & 11 & 1,8 & 17,2 & 1 & 0,2 & 1,6 & 17 & 2,8 & 26,6 \\
\hline $\begin{array}{l}\text { Bağlı olduğum belediyenin web sitesinde } \\
\text { işlem takip sistemi bulunması e-bel. tercih } \\
\text { etmemde etkilidir. }\end{array}$ & 64 & 10,7 & 1,25 & 56 & 9,3 & 87,5 & 4 & 0,7 & 6,3 & 0 & 0 & 0 & 4 & 0,7 & 6,3 \\
\hline $\begin{array}{l}\text { Bağlı olduğum belediyenin web sitesinde } \\
\text { herhangi bir konuda doldurulabilecek } \\
\text { şikayet formu yer almaktadır. }\end{array}$ & 64 & 10,7 & 1,67 & 43 & 7,2 & 67,2 & 10 & 1,7 & 15,6 & 0 & 0 & 0 & 11 & 1,8 & 17,2 \\
\hline $\begin{array}{l}\text { Bağll olduğum belediyenin web sitesi } \\
\text { üzerinden şikayet formu doldurmak e- bel. } \\
\text { tercih etmemde etkilidir. }\end{array}$ & 64 & 10,7 & 1,27 & 53 & 8,8 & 82,8 & 8 & 1,3 & 12,5 & 0 & 0 & 0 & 3 & 0,5 & 4,7 \\
\hline $\begin{array}{l}\text { Bağlı olduğum belediyenin web sitesinde } \\
\text { dilek, istek ve talep formu bulunmaktadır. }\end{array}$ & 64 & 10,7 & 1,77 & 43 & 7,2 & 67,2 & 7 & 1,2 & 10,9 & 0 & 0 & 0 & 14 & 2,3 & 21,9 \\
\hline $\begin{array}{l}\text { Bağli olduğum belediyenin web sitesi } \\
\text { üzerinden dilek, istek ve talep formu } \\
\text { doldurmak e-bel. tercih etmemde } \\
\text { etkilidir. }\end{array}$ & 64 & 10,7 & 1,23 & 53 & 8,8 & 82,8 & 9 & 1,5 & 14,1 & 0 & 0 & 0 & 2 & 0,3 & 3,1 \\
\hline $\begin{array}{l}\text { Bağlı olduğum belediyenin web sitesinde } \\
\text { cezalarımı ve vergilerimi ödeyebildiğim } \\
\text { bir sistem bulunmaktadır. }\end{array}$ & 64 & 10,7 & 1,91 & 42 & 7 & 65,6 & 4 & 0,7 & 6,3 & 0 & 0 & 0 & 18 & 3 & 28,1 \\
\hline $\begin{array}{l}\text { Bağll olduğum belediyenin web sitesi } \\
\text { üzerinden ceza-vergilerimi ödeyebilmek } \\
\text { e-bel. tercih etmemde etkilidir. }\end{array}$ & 64 & 10,7 & 1,22 & 56 & 9,3 & 87,5 & 5 & 0,8 & 7,8 & 0 & 0 & 0 & 3 & 0,5 & 4,7 \\
\hline
\end{tabular}

Kaynak: Yazarlar tarafından hazırlanmıştır. 
Tablo 14'de ankete katılan yurttaşların bağlı bulundukları belediyelerin sağladıkları e-belediyecilik uygulamaları ile ilgili bilgi düzeylerini ve tutumlarını ölçme amacı taşıyan bu soru, tüm katılımcıların \%10,7'si yani e-belediyecilik hizmetlerini kullandıklarını belirten katılımlar tarafından cevaplanmıştır.

Araştırma sonucunda katılımcıların "Bağlı olduğum web sitesinde herhangi bir hizmet alanında izin başvurusu yapılabilmektedir" şeklinde geliştirilen sorunun ilk öncülüne \%64,1'lik oranla "fikrim/bilgim yok" cevabını verdikleri görülmüsstür. Bu bağlamda, ankete katılan yurttaşların bağlı oldukları belediyenin web sitesinde herhangi bir hizmet alanında izin başvurusu yapılabilmesine yönelik fikir ve bilgi sahibi olmama düzeyleri; olma düzeylerine kıyasla daha yüksek oranda tespit edilmiştir. Aynı sorunun "Bağlı olduğum belediyenin web sitesinde herhangi bir konuda izin almaya yönelik başvuru yapılabilmesi e-belediyeciliği tercih etmemde etkilidir" şeklinde geliştirilen ikinci öncülünü ise, katılımcıların \% $\% 6,6$ 'lık oranla "evet" biçiminde cevaplandırdıkları tespit edilmiştir. Dolayısıyla bu sonuçlar, ankete katılan yurttaşların bağlı oldukları belediyenin web sitesinde herhangi bir hizmet alanında izin başvurusu yapılabildiği durumlarda, bu alanda belediyecilik işlemlerini dijital olarak gerçekleştirme eğilimlerinin artacağı biçiminde yorumlanabilmektedir.

Araştırma sonucunda katılımcıların "Bağll olduğum belediyenin web sitesinde işlem takip sistemi bulunmaktadır" şeklinde geliştirilen araştırma sorusunun üçüncü öncülüne \%54,7'lik oranda "evet" yanıtını verdikleri tespit edilmiştir. Bu bağlamda, ankete katılan yurttaşların bağlı oldukları belediyenin web sitesinde işlem takip sisteminin varlığına yönelik bilgi sahibi olma düzeylerinin, olmama düzeylerinden daha yüksek olduğu tespit edilmiştir. Bu araştırma sorusunun "Bağll olduğum belediyenin web sitesinde işlem takip sistemi bulunması e-belediyeciliği tercih etmemde etkilidir" biçiminde geliştirilen dördüncü öncülüne ise, katılımcıların \%87,5'inin "evet" yanıtını verdikleri görülmüştür. Dolayısıyla bu sonuçlar, ankete katılan yurttaşların bağlı oldukları belediyenin web sitesinde işlem takip sistemi bulunduğu durumlarda, belediyecilik işlemlerini dijital olarak gerçekleştirme eğilimlerinin artacağı biçiminde yorumlanabilmektedir.

Araştırma sonucunda katılımcıların "Bağhl olduğum belediyenin web sitesinde herhangi bir konuda doldurulabilecek şikayet formu yer almaktadır" ş̧eklinde geliştirilen araştırma sorusunun beşinci öncülüne $\% 67$ '2'lik oranda "evet" yanıtını verdikleri tespit edilmiştir. Bu bağlamda, ankete katılan yurttaşların bağlı oldukları belediyenin web sitesinde herhangi bir konuda doldurulabilecek şikayet formunun varlı̆̆ına yönelik bilgi sahibi olma düzeylerinin, olmama düzeylerinden daha yüksek olduğu tespit edilmiştir. Bu araştırma sorusunun "Bă̆gl olduğum belediyenin web sitesi üzerinden şikayet formu doldurmak e- belediyeciliği tercih etmemde etkilidir" biçiminde geliştirilen altıncı öncülüne ise, katılımcıların \%82,8'inin "evet" yanıtını verdikleri görülmüştür. Dolayısıyla bu sonuçlar, ankete katılan yurttaşların bağlı oldukları belediyenin web sitesinde herhangi bir konuda doldurabilecek şikayet formu bulunduğu durumlarda, belediyecilik işlemlerini dijital olarak gerçekleştirme eğilimlerinin artacağı biçiminde yorumlanabilmektedir.

Araştırma sonucunda katılımcıların "Bağlı olduğum belediyenin web sitesinde dilek, istek ve talep formu bulunmaktadır" ş̧eklinde geliştirilen araştırma sorusunun yedinci öncülüne $\% 67,2$ 'lik oranda "evet" yanıtını verdikleri tespit edilmiştir. Bu bağlamda, ankete katılan yurttaşların bağlı oldukları belediyenin web sitesinde dilek, istek ve talep formlarının varlığına yönelik bilgi sahibi olma düzeylerinin, olmama düzeylerinden daha yüksek olduğu tespit edilmiştir.Bu araştırma sorusunun "Bă̆ll olduğum belediyenin web sitesi üzerinden dilek, istek ve talep formu doldurmak, e-belediyeciliği tercih etmemde etkilidir" biçiminde geliştirilen sekizinci öncülüne ise katılımcıların \%82,8'inin "evet” yanıtını verdikleri görülmüştür.Dolayısıyla bu sonuçlar, ankete katılan yurttaşların bağlı oldukları belediyenin web sitesinde dilek, istek ve talep formu durumlarda, belediyecilik işlemlerini dijital olarak gerçekleştirme eğilimlerinin artacağı biçiminde yorumlanabilmektedir.

Araştırma sonucunda katılımcıların "Bağll olduğum belediyenin web sitesinde cezalarımı ve vergilerimi ödeyebildiğim bir sistem bulunmaktadır" şeklinde geliştirilen araştırma sorusunun dokuzuncu öncülüne, $\% 65,6$ 'lik oranda "evet" yanıtını verdikleri tespit edilmiştir. Bu bağlamda, ankete katılan yurttaşların bağlı oldukları belediyenin web sitesinde ceza ve vergilerini ödeyebildikleri bir sistemin varlığına yönelik bilgi sahibi olma düzeylerinin; olmama düzeylerinden daha yüksek olduğu tespit edilmiştir. Bu araştırma sorusunun " $B a \breve{g} l l$ olduğum belediyenin web sitesi üzerinden ceza-vergilerimi ödeyebilmek e-belediyeciliği tercih etmemde etkilidir" biçiminde geliştirilen onuncu öncülüne ise, katılımcıların \%87,5'inin "evet" yanıtını verdikleri görülmüştür. Dolayısıyla bu sonuçlar, ankete katılan yurttaşların bağlı oldukları belediyenin web sitesinde cezalarını ve vergilerini ödeyebildiği durumlarda, bu alanda belediyecilik işlemlerini dijital olarak gerçekleştirme eğilimlerinin artacağı biçiminde yorumlanabilmektedir. 
Tablo 15. Yurttaşların E-Belediyecilik Uygulamalarını İşlem Güvenliği Bazında Değerlendirmesi

\begin{tabular}{|l|c|c|c|}
\hline & $\mathrm{N}$ & Genel (\%) & Geçerli (\%) \\
\hline Evet, güvenlidir & 45 & 7,5 & 70,3 \\
Hayır, güvenli değildir & 4 & 0,7 & 6,3 \\
Kismen güvenlidir & 11 & 1,8 & 17,2 \\
Bilgim yok & 4 & 0,7 & 6,3 \\
Soruyu Cevaplayan Katılımcılar & 64 & 10,7 & 100 \\
Soruyu Cevaplamayan Katılımcılar & 536 & 89,3 & 0 \\
Toplam & 600 & 100 & - \\
\hline
\end{tabular}

Kaynak: Yazarlar tarafından hazırlanmıştır.

Tablo 15'te görüldüğü üzere; katılımcıların e-belediyecilik hizmetlerini işlem güvenliği bazında değerlendirmesini amaçlayan bu soru bağlamında, e-belediyecilik hizmetlerini kullandığını belirten katılımcıların \%70,3'ünün bu uygulamaları güvenli bulduğu, \%6,3'ünün güvenli bulmadığı, \%17,2'sinin kısmen güvenli bulduğu, \%6,3'ünün ise bu konuda bilgileri olmadığı sonucuna ulaşılmıştır. Dolayısıyla ankete katılan yurttaşların e-belediyecilik hizmetlerini genel olarak güvenli buldukları söylenebilmekle birlikte, bu durum yurttaşların e-belediyecilik hizmetlerini tercih etme sebepleri ile kıyaslandığında, bu hizmetlerin güvenilir olmasının ya da olmamasının e-belediyecelik hizmetlerini kullanma gerekçesi olarak yeterli öneme sahip olmadığı söylenebilmektedir.

Tablo 16. Yurttaşların E-Belediyecilik Uygulamaları İle İlgili Gizlilik/Güvenlik Kriterlerine Yönelik Bilgi Düzeylerinin ve Bu Kriterlerin Varlığının E-Belediyecilik Eğilimlerine Etkisinin Analizi

\begin{tabular}{|c|c|c|c|c|c|c|c|c|c|c|c|c|c|c|c|}
\hline & \multicolumn{2}{|c|}{$\begin{array}{l}\text { Soruyu } \\
\text { Cevaplayan } \\
\text { Katılımcılar }\end{array}$} & \multirow[t]{2}{*}{ Ort. } & \multicolumn{3}{|c|}{ Evet } & \multicolumn{3}{|c|}{ Hayır } & \multicolumn{3}{|c|}{ Kismen } & \multicolumn{3}{|c|}{$\begin{array}{c}\text { Fikrim/ Bilgim } \\
\text { Yok }\end{array}$} \\
\hline & $\mathrm{N}$ & $\%$ & & $\mathrm{~N}$ & $\begin{array}{c}\mathrm{G} \\
(\%)\end{array}$ & $\begin{array}{l}\text { Gçr } \\
(\%)\end{array}$ & $\mathrm{N}$ & $\begin{array}{c}\mathrm{G} \\
(\%)\end{array}$ & $\begin{array}{l}\text { Gçr } \\
(\%)\end{array}$ & $\mathrm{N}$ & $\begin{array}{c}\mathrm{G} \\
(\%)\end{array}$ & $\begin{array}{l}\text { Gçr } \\
(\%)\end{array}$ & $\mathrm{N}$ & $\begin{array}{c}\mathrm{G} \\
(\%)\end{array}$ & $\begin{array}{l}\text { Gçr } \\
(\%)\end{array}$ \\
\hline $\begin{array}{l}\text { Bağlı olduğum belediyenin web sitesinde } \\
\text { gizlilik/güvenlik politikasıyla ilgili } \\
\text { bilgiler bulunmaktadır. }\end{array}$ & 64 & 10,7 & 2,23 & 32 & 5,3 & 50 & 8 & 1,3 & 12,5 & 1 & 0,2 & 1,6 & 23 & 3,8 & 35,9 \\
\hline $\begin{array}{l}\text { Bağlı olduğum belediyenin web sitesinde } \\
\text { gizlilik/güvenlik politikasıyla ilgili } \\
\text { bilgilerin yer alması kişisel verilerimin } \\
\text { gizliliği açısından belediyeye güvenimi } \\
\text { artırır. }\end{array}$ & 64 & 10,7 & 1,41 & 52 & 8,7 & 81,3 & 4 & 0,7 & 6,3 & 2 & 0,3 & 3,1 & 6 & 1,0 & 9,4 \\
\hline $\begin{array}{l}\text { Bir işlem için bağlı olduğum belediyenin } \\
\text { web sitesine girdiğimde, işlemlerin } \\
\text { gizlilik ve güvenlik içinde yapılacağına } \\
\text { dair onay butonu vardır. }\end{array}$ & 64 & 10,7 & 2,45 & 24 & 4,0 & 37,5 & 13 & 2,2 & 20,3 & 1 & 0,2 & 1,6 & 26 & 4,3 & 40,6 \\
\hline $\begin{array}{l}\text { Bağlı olduğum belediyenin web sitesinde } \\
\text { bir işlem yapmak için bilgilerimin } \\
\text { güvende tutulacağına dair onay butonu } \\
\text { olması belediyeye güvenimi arttırır. }\end{array}$ & 64 & 10,7 & 1,36 & 52 & 8,7 & 81,3 & 6 & 1,0 & 9,4 & 1 & 0,2 & 1,6 & 5 & 0,8 & 7,8 \\
\hline $\begin{array}{c}\text { Bağlı olduğum belediyenin web sitesinde } \\
\text { kişisel bilgilerimin başka kamu } \\
\text { kurumları ile paylaşılacağı ifadesi yer } \\
\text { alır. }\end{array}$ & 64 & 10,7 & 2,89 & 5 & 0,8 & 7,8 & 28 & 4,7 & 43,8 & 0 & 0 & 0 & 31 & 5,2 & 48,4 \\
\hline $\begin{array}{l}\text { Bağlı olduğum belediyenin web sitesinde } \\
\text { kişisel bilgilerimin başka kamu } \\
\text { kurumları ile paylaş1lacağ ifadesinin } \\
\text { bulunması, belediyeye güvenimi arttırır. }\end{array}$ & 64 & 10,7 & 2,02 & 15 & 2,5 & 23,4 & 40 & 6,7 & 62,5 & 2 & 0,3 & 3,1 & 7 & 1,2 & 10,9 \\
\hline $\begin{array}{l}\text { Bağlı olduğum belediyenin web sitesinde } \\
\text { kişisel bilgilerimin kimseyle } \\
\text { paylaşılmayacağ } 1 \text { ifadesi yer alır. }\end{array}$ & 64 & 10,7 & 2,75 & 18 & 3,0 & 28,1 & 12 & 2,0 & 18,8 & 2 & 0,3 & 3,1 & 32 & 5,3 & 50 \\
\hline $\begin{array}{l}\text { Bağlı olduğum belediyenin web sitesinde } \\
\text { kişisel bilgilerimin kimseyle } \\
\text { paylaşılmayacağı ifadesi, belediyeye } \\
\text { güvenimi arttırır. }\end{array}$ & 64 & 10,7 & 1,31 & 55 & 9,2 & 85,9 & 3 & 0,5 & 4,7 & 1 & 0,2 & 1,6 & 5 & 0,8 & 7,8 \\
\hline
\end{tabular}




\begin{tabular}{|c|c|c|c|c|c|c|c|c|c|c|c|c|c|c|c|}
\hline $\begin{array}{l}\text { Bağlı olduğum belediyenin web sitesinde } \\
\text { kendi hesabımı oluş̧urup, özel şifremle } \\
\text { giriş yapabilme imkanı bulunmaktadır. }\end{array}$ & 64 & 10,7 & 1,88 & 36 & 6,0 & 56,3 & 14 & 2,3 & 21,9 & 0 & 0 & 0 & 14 & 2,3 & 21,9 \\
\hline $\begin{array}{l}\text { Bağlı olduğum belediyenin web sitesinde } \\
\text { kendi şifremle işlem yapabilmem, } \\
\text { bilgilerimin korunması noktasında } \\
\text { belediyeye güvenimi arttırır. }\end{array}$ & 64 & 10,7 & 1,48 & 47 & 7,8 & 73,4 & 9 & 1,5 & 14,1 & 2 & 0,3 & 3,1 & 6 & 1,0 & 9,4 \\
\hline $\begin{array}{l}\text { Bağlı olduğum belediyenin web sitesinde } \\
\text { dijital imza ile işlem yapabiliyorum. }\end{array}$ & 64 & 10,7 & 2,69 & 8 & 1,3 & 12,5 & 30 & 5,0 & 46,9 & 0 & 0 & 0 & 26 & 4,3 & 40,6 \\
\hline $\begin{array}{l}\text { Bağlı olduğum belediyenin web sitesinde } \\
\text { dijital imza ile işlem yapmak; } \\
\text { bilgilerimin korunması noktasında } \\
\text { belediyeye güvenimi arttırır. }\end{array}$ & 64 & 10,7 & 1,72 & 43 & 7,2 & 67,2 & 6 & 1,0 & 9,4 & 5 & 0,8 & 7,8 & 10 & 1,7 & 15,6 \\
\hline $\begin{array}{l}\text { Bağlı olduğum belediyenin web } \\
\text { sitesinde, şifrenin unutulması gibi bir } \\
\text { durumda, güvenlik doğrulama ve } \\
\text { hesabımı kurtarabilme imkanım } \\
\text { bulunmaktadır. }\end{array}$ & 64 & 10,7 & 2,55 & 24 & 4,0 & 37,5 & 10 & 1,7 & 15,6 & 1 & 0,2 & 1,6 & 29 & 4,8 & 45,3 \\
\hline $\begin{array}{l}\text { Bağlı olduğum belediyenin web } \\
\text { sitesinde, güvenlik doğrulama ve } \\
\text { hesabımı kurtarabilme imkânının olması, } \\
\text { belediyeye olan güvenimi arttırır. }\end{array}$ & 64 & 10,7 & 1,47 & 51 & 8,5 & 79,7 & 4 & 0,7 & 6,3 & 1 & 0,2 & 1,6 & 8 & 1,3 & 12,5 \\
\hline $\begin{array}{c}\text { Bağlı olduğum belediyenin web } \\
\text { sitesinde, Cep telefonu ile kimlik } \\
\text { doğrulama, 3D Güvenlik sistemi } \\
\text { bulunmaktadır. }\end{array}$ & 64 & 10,7 & 2,61 & 20 & 3,3 & 31,3 & 14 & 2,3 & 21,9 & 1 & 0,2 & 1,6 & 29 & 4,8 & 45,3 \\
\hline $\begin{array}{l}\text { Bağlı olduğum belediyenin web } \\
\text { sitesinde, Cep telefonu ile kimlik } \\
\text { doğrulama, 3D Güvenlik sisteminin } \\
\text { bulunması, bilgilerimin korunması için } \\
\text { belediyeye olan güvenimi arttırır. }\end{array}$ & 64 & 10,7 & 1,48 & 52 & 8,7 & 81,3 & 2 & 0,3 & 3,1 & 1 & 0,2 & 1,6 & 9 & 1,5 & 14,1 \\
\hline $\begin{array}{l}\text { Bağlı olduğum belediyenin web } \\
\text { sitesinde, Cep telefonu ile kimlik } \\
\text { doğrulama ve 3D Güvenlik sisteminin } \\
\text { olmaması işlem yapmamı engellemez. }\end{array}$ & 64 & 10,7 & 1,91 & 28 & 4,7 & 43,8 & 23 & 3,8 & 35,9 & 4 & 0,7 & 6,3 & 9 & 1,5 & 14,1 \\
\hline
\end{tabular}

Kaynak: Yazarlar tarafından hazırlanmıştır.

Tablo 16'da görüldüğü üzere ankete katılan yurttaşların e-belediyecilik uygulamaları ile ilgili gizlilik/güvenlik kriterleri hakkındaki bilgi düzeylerini ve e-belediyecilik uygulamalarının gizlilik ve güvenlik kriterlerini sağlamasının e-belediyeciliğe yönelik tutumları üzerindeki etkisini ölçme amacı taşıyan bu soru, tüm katılımcıların \%10,7'si yani e-belediyecilik hizmetlerini kullandığını belirten katılımcılar tarafından cevaplanmıştır.

Araştırma sonucunda katılımcıların "Băğl olduğum belediyenin web sitesinde gizlilik/güvenlik politikasıyla ilgili bilgiler bulunmaktadır" şeklinde geliştirilen sorunun ilk öncülüne \%50'lik oranla "evet" yanıtını verdikleri görülmüştür. Bu bağlamda, ankete katılan yurttaşların bağlı oldukları belediyenin web sitesinde gizlilik/güvenlik politikalarının varlı̆̆ına ilişkin fikir ve bilgi sahibi olma düzeyleri; olmama düzeylerine kıyasla daha yüksek oranda tespit edilmiştir.Aynı sorunun "Bağlı olduğum belediyenin web sitesinde gizlilik/güvenlik politikasıyla ilgili bilgilerin yer alması kişisel verilerimin gizliliği açısından belediyeye güvenimi artırı" şeklinde geliştirilen ikinci öncülünü ise, katılımcıların \%81,3'lük oranla "evet" yanıtını vermiştir. Dolayısıyla, bu sonuçlar yurttaşların e-belediyecilik işlemleri gerçekleştirdikleri belediyelerin web sitelerinde gizlilik/güvenlik politikalarına yönelik bilgilerin bulunması durumunda belediyelere güven eğilimlerinin arttığı biçiminde yorumlanabilmektedir.

Araştırma sonucunda katılımcıların "Bir işlem için bağlı olduğum belediyenin web sitesine girdiğimde, işlemlerin gizlilik ve güvenlik içinde yapılacağına dair onay butonu vardır" şeklinde geliştirilen sorunun üçüncü öncülüne \%40,6'lık oranla "fikrim/bilgim yok" yanıtını verdikleri görülmüştür. Bu bağlamda, ankete katılan yurttaşların bağlı oldukları belediyenin web sitesinde işlemlerin gizlilik ve güvenlik içinde yapılacağına yönelik onay butonunun varlığına ilişkin fikir ve bilgi sahibi olmama düzeyleri; olma düzeylerine kıyasla daha yüksek oranda tespit edilmiştir. Aynı sorunun "Bağll olduğum belediyenin web sitesinde bir işlem yapmak için bilgilerimin güvende tutulacağına dair onay butonu olması belediyeye güvenimi arttırır" şeklinde geliştirilen dördüncü öncülünü ise, katılımcıların \%81,3'lük oranla "evet" yanıtını verdikleri görülmüştür. Dolayısıyla, bu sonuçlar yurttaşların belediyelerle paylaştıkları kişisel verilerin güvende tutulmasına yönelik onay 
mekanizmasının işlerlik kazanması durumunda belediyelere güven eğilimlerinin arttığı biçiminde yorumlanabilmektedir.

Araştırma sonucunda katılımcıların "Bağll olduğum belediyenin web sitesinde kişisel bilgilerimin başka kamu kurumları ile paylaşılacağ ifadesi yer alır" şeklinde geliştirilen sorunun beşinci öncülüne \%7,8'lik oranla “evet”, \%43,8'lik oranla "hayır", \%48,4'lük oranla "fikrim/bilgim yok" yanıtını verdikleri görülmüştür. Bu bağlamda, ankete katılan yurttaşların bağlı oldukları belediyenin web sitesinde kişisel bilgilerinin başka kamu kurumları ile paylaşılacağı ifadesinin varllğına ilişkin fikir ve bilgi sahibi olmama düzeyleri; olma düzeylerine kıyasla daha yüksek oranda tespit edilmiştir. Aynı sorunun "Bağlı olduğum belediyenin web sitesinde kişisel bilgilerimin başka kamu kurumları ile paylaşılacağı ifadesinin bulunması, belediyeye güvenimi arttırır" şeklinde geliştirilen altıncı öncülünü ise, katılımcıların \%62,5'lik oranla "hayır", \%10,9'luk oranla "fikrim/bilgim yok" biçiminde yanıtladıkları tespit edilmiştir. Dolayısıyla, bu sonuçlar yurttaşların belediyelerle paylaştıkları kişisel verilerin diğer kamu kuruluşları ile paylaşılması durumunda belediyelere güven eğilimlerinin azaldığı biçiminde yorumlanabilmektedir.

Araştırma sonucunda katılımcıların "Bağlı olduğum belediyenin web sitesinde kişisel bilgilerimin kimseyle paylaşılmayacağı ifadesi yer alır" ş̧eklinde geliştirilen sorunun yedinci öncülüne \%50'lik oranla "fikrim/bilgim yok" yanıtını verdikleri görülmüştür. Bu bağlamda, ankete katılan yurttaşların bağlı oldukları belediyenin web sitesinde kişisel bilgilerinin kimse ile paylaşılmayacağı ifadesinin varlığına ilişkin fikir ve bilgi sahibi olmama düzeyleri; olma düzeylerine kıyasla daha yüksek oranda tespit edilmiştir. Aynı sorunun "Bağlı olduğum belediyenin web sitesinde kişisel bilgilerimin kimseyle paylaşılmayacağı ifadesi, belediyeye güvenimi arttırır" şeklinde geliştirilen sekizinci öncülünü ise, katılımcıların \%85,9'luk oranla "evet" yanıtını verdikleri görülmüştür. Dolayısıyla, bu sonuçlar yurttaşların belediyelerle paylaştıkları kişisel verilerin kimse ile paylaşılmaması durumunda belediyelere güven eğilimlerinin arttığı biçiminde yorumlanabilmektedir.

Araştırma sonucunda katılımcıların "Bağll olduğum belediyenin web sitesinde kendi hesabımı oluşturup, özel şifremle giriş yapabilme imkanı bulunmaktadır” ş̧eklinde geliştirilen sorunun dokuzuncu öncülüne, \%56,3'lük oranla "evet"yanıtını verdikleri görülmüştür. $\mathrm{Bu}$ bağlamda, ankete katılan yurttaşların bağlı oldukları belediyenin web sitesinde kişisel hesap oluşturup; özel şifreleri ile işlem yapabilme hizmetinin varlığına yönelik fikir ve bilgi sahibi olma düzeyleri; olmama düzeylerine kıyasla daha yüksek oranda tespit edilmiştir. Aynı sorunun "Băglı olduğum belediyenin web sitesinde kendi şifremle işlem yapabilmem, bilgilerimin korunmasl noktasında belediyeye güvenimi arttırı" ş̧eklinde geliştirilen onuncu öncülünü ise, katılımcıların \%73,4'lük oranla "evet" yanıtını verdikleri görülmüştür. Dolayısıyla, bu sonuçlar yurttaşların belediyelerin web sitelerinde kişisel hesap oluşturabilmeleri ve özel şifreleri ile işlem yapabilmeleri durumunda belediyelere güven eğilimlerinin arttığı biçiminde yorumlanabilmektedir.

Araştırma sonucunda katılımcıların "Bağll olduğum belediyenin web sitesinde dijital imza ile işlem yapabiliyorum" şeklinde geliştirilen sorunun onbirinci öncülüne \%46,9'luk oranla "hayır", \%40,6'l1k oranla "fikrim/bilgim yok" cevabını verdikleri görülmüştür. Bu bağlamda, ankete katılan yurttaşların bağlı oldukları belediyenin web sitesinde dijital imza ile işlem yapabilme hizmetinin varlığına yönelik fikir ve bilgi sahibi olmama düzeyleri; olma düzeylerine klyasla daha yüksek oranda tespit edilmiştir. Aynı sorunun "Bağlı olduğum belediyenin web sitesinde dijital imza ile işlem yapmak; bilgilerimin korunması noktasında belediyeye güvenimi arttırır" şeklinde geliştirilen onikinci öncülünü ise, katılımcıların \%67,2'lik oranla "evet" yanıtını verdikleri görülmüştür. Dolayısıyla, bu sonuçlar yurttaşların belediyelerin web sitelerinde dijital imza ile işlem yapabilmeleri durumunda belediyelere güven eğilimlerinin arttı̆̆ biçiminde yorumlanabilmektedir.

Araştırma sonucunda katılımcıların "Bağhl olduğum belediyenin web sitesinde, şifrenin unutulması gibi bir durumda, güvenlik doğrulama ve hesabımı kurtarabilme imkanım bulunmaktadır" şeklinde geliştirilen sorunun onüçüncü öncülüne $\% 45,3$ 'lük oranla "fikrim/bilgim yok" yanıtını verdikleri görülmüştür. Bu bağlamda, ankete katılan yurttaşların bağlı oldukları belediyenin web sitesinde şifrenin unutulması gibi bir durumda, güvenlik doğrulama ve hesabı kurtarabilme imkanının varlığına yönelik fikir ve bilgi sahibi olmama düzeyleri; olma düzeylerine kıyasla daha yüksek oranda tespit edilmiştir. Aynı sorunun "Bağll olduğum belediyenin web sitesinde, güvenlik doğrulama ve hesabımı kurtarabilme imkânının olması, belediyeye olan güvenimi arttırı"” şeklinde geliştirilen ondördüncü öncülünü ise, katılımcıların \%79,7'lik oranla "evet" yanıtını verdikleri görülmüştür. Dolayısıyla, bu sonuçlar yurttaşların belediyelerin web sitelerinde şifrenin unutulmasına benzer bir soruna bağlı olarak güvenlik doğrulama ve hesabı kurtarabilme işlemleri gerçekleştirebildikleri durumlarda belediyelere güven eğilimlerinin arttı̆̆ biçiminde yorumlanabilmektedir.

Araştırma sonucunda katılımcıların "Bağg olduğum belediyenin web sitesinde, Cep telefonu ile kimlik doğrulama, 3D Güvenlik sistemi bulunmaktadır" ş̧eklinde geliştirilen sorunun onbeşinci öncülüne \%31,3'lük 
oranla "evet", \%21,9'lük oranla "hayır", \%1,6'lik oranla kısmen, \%45,3'lük oranla "fikrim/bilgim yok" cevabını verdikleri görülmüştür. Bu bağlamda, ankete katılan yurttaşların bağlı oldukları belediyenin web sayfasında cep telefonu ile kimlik doğrulama ve 3D Güvenlik sisteminin varlığına yönelik fikir ve bilgi sahibi olmama düzeyleri; olma düzeylerine kıyasla daha yüksek oranda tespit edilmiştir. Aynı sorunun "Bağlı olduğum belediyenin web sitesinde, Cep telefonu ile kimlik doğrulama, 3D Güvenlik sisteminin bulunmast, bilgilerimin korunması için belediyeye olan güvenimi arttırır" şeklinde geliştirilen onaltıncı öncülüne ise, katılımcıların \%81,3'lük oranla "evet" yanıtını verdikleri görülmüştür. Dolayısıyla, bu sonuçlar yurttaşların belediyelerin web sitelerinde cep telefonu ile kimlik doğrulama ve 3D Güvenlik sistemi ile işlem gerçekleştirebildikleri durumlarda belediyelere duydukları güvenin arttığı biçiminde yorumlanabilmektedir.

Aynı sorunun "Bă̆ll olduğum belediyenin web sitesinde, Cep telefonu ile kimlik doğrulama ve 3D Güvenlik sisteminin olmaması işlem yapmamı engellemez" şeklinde geliştirilen onyedinci öncülünü ise, katılımcıların $\% 43,8$ 'lik oranla "evet", \%35,9'luk oranla "hayır", \%6,3'lük oranla "kismen”, \%14,1'lik oranla "fikrim/bilgim yok" biçiminde cevaplandırdıkları sonucuna ulaşılmıştır. Bu bağlamda, ankete katılan yurttaşların bağlı oldukları belediyenin web sitesinde cep telefonu ile kimlik doğrulama ve 3D Güvenlik sisteminin bulunmamasının işlem yapmayı engellemediği yönünde elde edilen bulgular, engellediği veya yurttaşların bu konuda bilgisi/fikri olmadığına ilişkin verilere kıyasla daha yüksek oranda tespit edilmiştir. Ayrıca, bu sorunun onaltıncı ve onyedinci öncüllerinde elde edilen veriler birlikte incelendiğinde; yurttaşların bağlı oldukları belediyenin web sitesinde cep telefonu ile kimlik doğrulama ve 3D Güvenlik sisteminin bulunmasının yurttaşların belediyelere duydukları güven düzeyi üzerinde pozitif etkisi olmasına rağmen; bulunmamasının ise işlem yapmama açısından çok yükssek bir negatif etki oluşturmadığı biçiminde yorumlanabilmektedir.

Tablo 17. Yurttaşların E-Belediyecilik Uygulamaları İle İlgili Kullanılabilirlik Kriterlerine Yönelik Bilgi Düzeylerinin ve Bu Kriterlerin Varlığının E-Belediyecilik Eğilimleri Üzerinde Etkisinin Analizi

\begin{tabular}{|c|c|c|c|c|c|c|c|c|c|c|c|c|c|c|c|}
\hline & \multicolumn{2}{|c|}{$\begin{array}{c}\text { Soruyu } \\
\text { Cevaplayan } \\
\text { Katılımcilar }\end{array}$} & \multirow{2}{*}{\begin{tabular}{|c|} 
Ort. \\
$\%$ \\
\end{tabular}} & \multicolumn{3}{|c|}{ Evet } & \multicolumn{3}{|c|}{ Hayır } & \multicolumn{3}{|c|}{ Kismen } & \multicolumn{3}{|c|}{$\begin{array}{c}\text { Fikrim/ Bilgim } \\
\text { Yok }\end{array}$} \\
\hline & $\mathrm{N}$ & $\%$ & & $\mathrm{~N}$ & $\begin{array}{c}\mathrm{G} \\
(\%) \\
\end{array}$ & $\begin{array}{l}\text { Gçr } \\
(\%) \\
\end{array}$ & $\mathrm{N}$ & \begin{tabular}{c|c}
$\mathrm{G}$ \\
$(\%)$ \\
\end{tabular} & $\begin{array}{l}\text { Gçr } \\
(\%)\end{array}$ & $\mathrm{N}$ & $\begin{array}{c}\mathrm{G} \\
(\%) \\
\end{array}$ & $\begin{array}{l}\text { Gçr } \\
(\%) \\
\end{array}$ & $\mathrm{N}$ & $\mathrm{G}(\%)$ & $\begin{array}{l}\text { Gçr } \\
(\%)\end{array}$ \\
\hline $\begin{array}{l}\text { Bağlı olduğum belediyenin web sitesine erişim } \\
\text { kolaydır. }\end{array}$ & 64 & 10,7 & 1,17 & 59 & 9,8 & 92,2 & 1 & 0,2 & 1,6 & 2 & 0,3 & 3,1 & 2 & 0,3 & 3,1 \\
\hline $\begin{array}{l}\text { Bağlı olduğum belediyenin web sitesine erişimin } \\
\text { kolay olmas1 e-bel. tercih etmemde etkilidir. }\end{array}$ & 64 & 10,7 & 1,08 & 61 & 10,2 & 95,3 & 2 & 0,3 & 3,1 & 0 & 0 & 0 & 1 & 0,2 & 1,6 \\
\hline $\begin{array}{l}\text { Bağlı olduğum belediyenin web sitesi hızlı } \\
\text { yüklenmektedir. }\end{array}$ & 64 & 10,7 & 1,44 & 49 & 8,2 & 76,6 & 4 & 0,7 & 6,3 & 9 & 1,5 & 14,1 & 2 & 0,3 & 3,1 \\
\hline $\begin{array}{l}\text { Bağlı olduğum belediyenin web sitesinin hızlı } \\
\text { yüklenmesi; kullanım kolaylığı sağladığı için } \\
\text { işlemlerimi e. bel. ile gerçekleştirmemde etkilidir }\end{array}$ & 64 & 10,7 & 1,08 & 61 & 10,2 & 95,3 & 2 & 0,3 & 3,1 & 0 & 0 & 0 & 1 & 0,2 & 1,6 \\
\hline $\begin{array}{l}\text { Bağlı olduğum belediyenin web sitesinde site } \\
\text { haritası bulunmaktadır. }\end{array}$ & 64 & 10,7 & 1,56 & 52 & 8,7 & 81,3 & 0 & 0 & 0 & 0 & 0 & 0 & 12 & 2,0 & 18,8 \\
\hline $\begin{array}{l}\text { Bağlı olduğum belediyenin web sitesinde site } \\
\text { haritasının bulunması, aradığımı kolay bulmamı ve } \\
\text { işlemlerimi kolay gerçekleştirmemi sağladığ için } \\
\text { e. bel. tercih etmemde etkilidir. }\end{array}$ & 64 & 10,7 & 1,39 & 51 & 8,5 & 79,7 & 7 & 1,2 & 10,9 & 0 & 0 & 0 & 6 & 1,0 & 9,4 \\
\hline $\begin{array}{l}\text { Bağlı olduğum belediyenin web sitesinde arama } \\
\text { motoru vardır. }\end{array}$ & 64 & 10,7 & 1,55 & 51 & 8,5 & 79,7 & 2 & 0,3 & 3,1 & 0 & 0 & 0 & 11 & 1,8 & 17,2 \\
\hline $\begin{array}{l}\text { Bağlı olduğum belediyenin web sitesinde arama } \\
\text { motorunun bulunması, aradığımı kolay bulmamı ve } \\
\text { isslemlerimi kolay gerçekleştirmemi sağladığ için } \\
\text { e-bel. tercih etmemde etkilidir. }\end{array}$ & 64 & 10,7 & 1,25 & 55 & 9,2 & 85,9 & 5 & 0,8 & 7,8 & 1 & 0,2 & 1,6 & 3 & 0,5 & 4,7 \\
\hline $\begin{array}{l}\text { Bağlı olduğum belediyenin web sitesinde yer alan } \\
\text { bağlantı linkleri doğru ve hızlı bir şekilde } \\
\text { çalışmaktadır. }\end{array}$ & 64 & 10,7 & 1,63 & 45 & 7,5 & 70,3 & 4 & 0,7 & 6,3 & 9 & 1,5 & 14,1 & 6 & 1,0 & 9,4 \\
\hline $\begin{array}{l}\text { Bağlı olduğum belediyenin web sitesinde linklerin } \\
\text { doğru ve hızlı çalışması, kullanım kolaylığ } \\
\text { sağladığ için e-bel. tercih etmemde etkilidir. }\end{array}$ & 64 & 10,7 & 1,16 & 60 & 10,0 & 93,8 & 1 & 0,2 & 1,6 & 0 & 0 & 0 & 3 & 0,5 & 4,7 \\
\hline $\begin{array}{l}\text { Bağlı olduğum belediyenin web sitesinde kayma, } \\
\text { karakterlerin, görsel öğelerin karmaşıklığ gibi bir } \\
\text { sorun yoktur. }\end{array}$ & 64 & 10,7 & 1,63 & 35 & 5,8 & 54,7 & 23 & 3,8 & 35,9 & 1 & 0,2 & 1,6 & 5 & 0,8 & 7,8 \\
\hline $\begin{array}{l}\text { Bağlı olduğum belediyenin web sitesinde herhangi } \\
\text { bir kayma ve karışılığın olmaması, kullanım } \\
\text { kolaylığı sağladığı için e-bel. tercih etmemde } \\
\text { etkilidir. }\end{array}$ & 64 & 10,7 & 1,19 & 58 & 9,7 & 90,6 & 2 & 0,3 & 3,1 & 2 & 0,3 & 3,1 & 2 & 0,3 & 3,1 \\
\hline
\end{tabular}




\begin{tabular}{|c|c|c|c|c|c|c|c|c|c|c|c|c|c|c|c|}
\hline $\begin{array}{l}\text { Bağlı olduğum belediyenin web sitesi çıktı } \\
\text { alınmasına uygun bir yapıdadır. }\end{array}$ & 64 & 10,7 & 1,80 & 44 & 7,3 & 68,8 & 4 & 0,7 & 6,3 & 1 & 0,2 & 1,6 & 15 & 2,5 & 23,4 \\
\hline $\begin{array}{l}\text { Bağlı olduğum belediyenin web sitesinden çıtıtı } \\
\text { alınması, kullanım kolaylığı sağladığı için e-bel. } \\
\text { tercih etmemde etkilidir. }\end{array}$ & 64 & 10,7 & 1,31 & 55 & 9,2 & 85,9 & 3 & 0,5 & 4,7 & 1 & 0,2 & 1,6 & 5 & 0,8 & 7,8 \\
\hline $\begin{array}{l}\text { Bağlı olduğum belediyenin web sitesinde } \\
\text { yabancı/yerli dil seçim olanağı bulunmaktadır. }\end{array}$ & 64 & 10,7 & 3,27 & 9 & 1,5 & 14,1 & 10 & 1,7 & 15,6 & 0 & 0 & 0 & 45 & 7,5 & 70,3 \\
\hline $\begin{array}{l}\text { Bağlı olduğum belediyenin web sitesinde dil seçim } \\
\text { olanağının olması kullanım kolaylığı sağladığı için } \\
\text { e-bel. tercih etmemde etkilidir. }\end{array}$ & 64 & 10,7 & 1,95 & 27 & 4,5 & 42,2 & 24 & 4,0 & 37,5 & 2 & 0,3 & 3,1 & 11 & 1,8 & 17,2 \\
\hline $\begin{array}{l}\text { Bağlı olduğum bel.web sitesi mobil cihazlardan } \\
\text { yüklenmeye uygun bir yapıdadır. }\end{array}$ & 64 & 10,7 & 2,33 & 30 & 5,0 & 46,9 & 7 & 1,2 & 10,9 & 3 & 0,5 & 4,7 & 24 & 4,0 & 37,5 \\
\hline $\begin{array}{l}\text { Bağlı olduğum belediyenin web sitesinin mobil } \\
\text { cihazlardan yüklenmeye uygun bir yapida olması, } \\
\text { kullanım kolaylığı sağladığı için işlemlerimi e-bel. } \\
\text { gerçekleştirmemde etkilidir. }\end{array}$ & 64 & 10,7 & 1,47 & 49 & 8,2 & 76,6 & 7 & 1,2 & 10,9 & 1 & 0,2 & 1,6 & 7 & 1,2 & 10,9 \\
\hline $\begin{array}{l}\text { Bağlı olduğum belediyenin web sitesinde çevrimiçi } \\
\text { formlar (İletişim f., dilekçe gibi) bulunmaktadır. }\end{array}$ & 64 & 10,7 & 1,44 & 54 & 9,0 & 84,4 & 1 & 0,2 & 1,6 & 0 & 0 & 0 & 9 & 1,5 & 14,1 \\
\hline $\begin{array}{l}\text { Bağlı olduğum belediyenin web sitesinde çevrimiçi } \\
\text { formların bulunması, kullanım kolaylığı sağladığ } 1 \\
\text { için işlemlerimi e-bel. gerçekleştirmemde etkilidir. }\end{array}$ & 64 & 10,7 & 1,36 & 50 & 8,3 & 78,1 & 9 & 1,5 & 14,1 & 1 & 0,2 & 1,6 & 4 & 0,7 & 6,3 \\
\hline $\begin{array}{l}\text { Bağlı olduğum belediyenin web sitesinde } \\
\text { kullanılan yazı fontu ve büyüklügü rahat okunmaya } \\
\text { elverişlidir. }\end{array}$ & 64 & 10,7 & 1,11 & 61 & 10,2 & 95,3 & 1 & 0,2 & 1,6 & 0 & 0 & 0 & 2 & 0,3 & 3,1 \\
\hline $\begin{array}{l}\text { Bağlı olduğum belediyenin web sitesinde yazıların } \\
\text { kolayca okunabilmesi, kullanım kolaylığı sağladığı } \\
\text { için e-bel. tercih etmemde etkilidir. }\end{array}$ & 64 & 10,7 & 1,14 & 60 & 10,0 & 93,8 & 1 & 0,2 & 1,6 & 1 & 0,2 & 1,6 & 2 & 0,3 & 3,1 \\
\hline $\begin{array}{l}\text { Bağlı olduğum belediyenin web sitesinde sayfa } \\
\text { uzunluğu optimal ölçüdedir. }\end{array}$ & 64 & 10,7 & 1,22 & 57 & 9,5 & 89,1 & 3 & 0,5 & 4,7 & 1 & 0,2 & 1,6 & 3 & 0,5 & 4,7 \\
\hline $\begin{array}{l}\text { Bağl1 olduğum belediyenin web sitesinin optimal } \\
\text { ölçüde olması, kullanım kolaylığı sağladığı için e- } \\
\text { bel. tercih etmemde etkilidir. }\end{array}$ & 64 & 10,7 & 1,19 & 59 & 9,8 & 92,2 & 1 & 0,2 & 1,6 & 1 & 0,2 & 1,6 & 3 & 0,5 & 4,7 \\
\hline $\begin{array}{l}\text { Bağlı olduğum belediyenin web sitesindeki bilgiler } \\
\text { günceldir. }\end{array}$ & 64 & 10,7 & 1,47 & 49 & 8,2 & 76,6 & 6 & 1,0 & 9,4 & 3 & 0,5 & 4,7 & 6 & 1,0 & 9,4 \\
\hline $\begin{array}{l}\text { Bağlı olduğum belediyenin web sitesindeki } \\
\text { bilgilerin güncel olması; güncel bilgiye ulaşmamı } \\
\text { kolaylaştırdığı için e-bel. tercih etmemde etkilidir. }\end{array}$ & 64 & 10,7 & 1,22 & 57 & 9,5 & 89,1 & 3 & 0,5 & 4,7 & 1 & 0,2 & 1,6 & 3 & 0,5 & 4,7 \\
\hline $\begin{array}{l}\text { Bağlı olduğum belediyenin web sitesinde } \\
\text { navigasyon hizmeti bulunmaktadır. }\end{array}$ & 64 & 10,7 & 2,28 & 30 & 5,0 & 46,9 & 10 & 1,7 & 15,6 & 0 & 0 & 0 & 24 & 4,0 & 37,5 \\
\hline $\begin{array}{l}\text { Bağlı olduğum belediyenin web sitesinde } \\
\text { navigasyon hizmetinin bulunması; kullanım } \\
\text { kolaylığı sağladığı için e-bel. tercih etmemde } \\
\text { etkilidir. }\end{array}$ & 64 & 10,7 & 1,75 & 40 & 6,7 & 62,5 & 11 & 1,8 & 17,2 & 2 & 0,3 & 3,1 & 11 & 1,8 & 17,2 \\
\hline $\begin{array}{l}\text { Bağl1 olduğum belediyenin web sitesi engelli } \\
\text { girişine uyumludur. }\end{array}$ & 64 & 10,7 & 3,39 & 6 & 1,0 & 9,4 & 10 & 1,7 & 15,6 & 1 & 0,2 & 1,6 & 47 & 7,8 & 73,4 \\
\hline
\end{tabular}

Kaynak: Yazarlar tarafından hazırlanmıştır.

Tablo 17'de görüldüğü üzere ankete katılan yurttaşların e-belediyecilik uygulamaları ile ilgili kullanılabilirlik kriterleri hakkındaki bilgi düzeylerini ve e-belediyecilik uygulamalarının bu kriterleri sağlamasının ebelediyeciliğe yönelik tutumları üzerindeki etkisini ölçme amacı taşıyan bu soru, tüm katılımcıların \%10,7'si yani e-belediyecilik hizmetlerini kullandığını belirten katılımcılar tarafından cevaplanmıştır.

Araştırma sonucunda ankete katılan yurttaşların çoğunun "Bă̆lı olduğum belediyenin web sitesine erişim kolaydır", "Bă̆ll olduğum belediyenin web sitesi hızl yüklenmektedir", "Bağll olduğum belediyenin web sitesinde site haritası bulunmaktadır", "Bağll olduğum belediyenin web sitesinde arama motoru vardır", "Bağll olduğum belediyenin web sitesinde yer alan bağlantı linkleri doğru ve hızlı bir şekilde çalışmaktadır", "Bă̆lı olduğum belediyenin web sitesinde kayma, karakterlerin, görsel öğelerin karmaşıklı̆̆ gibi bir sorun yoktur", "Bağlı olduğum belediyenin web sitesi çıktı alınmasına uygun bir yapıdadır", "Bağlı olduğum belediyenin web sitesinde yabancl/yerli dil seçim olană̆ bulunmaktadır", "Bağll olduğum belediyenin web sitesi mobil cihazlardan yüklenmeye uygun bir yapıdadır", "Bă̆ll olduğum belediyenin web sitesinde çevrimiçi formlar (Illetişim formu, dilekçe gibi) bulunmaktadır", "Bağll olduğum belediyenin web sitesinde kullanılan yazı fontu ve büyüklüğ̈̈ rahat okunmaya elverişlidir", "Bağll olduğum belediyenin web sitesinde sayfa uzunluğu optimal ölçüdedir", "Bă̆ll olduğum belediyenin web sitesinde navigasyon hizmeti bulunmaktadır" öncüllerine ve bu öncüllere bağlı olarak geliştirilen eğilim öncüllerine“evet" yanıtını verdikleri görülmüş̧ür. Dolayısıyla yurttaşlar açısından e-belediyecilik hizmeti sağladıkları web sitesinin kullanılabilirlik kriterlerini karşıladığı ve kriterleri 
sağlaması dolayısıyla belediyecilik işlemlerini dijital olarak gerçekleştirme eğilimlerinin arttığı sonucuna ulaşılabilmektedir.

Araştırma sonuçlarına göre, yurttaşların çoğu açısından kullanılabilirlik kriterleri arasında fikir/bilgi sahibi olmadıkları tek öncül "bağll oldukları belediyenin web sitesinin engelli girişine uyumlu olması"dır. Ankete katılan yurttaşların bu öncüle \%73,4'lük oranla "fikrim/bilgim yok" cevabını verdikleri görülmüş olup, bu bağlamda, yurttaşların bağlı oldukları belediyenin web sitelerinin engelli girişine uyumlu olması ile ilgili fikir ve bilgi sahibi olmama düzeylerinin, olma düzeylerine kıyasla daha yüksek oranda olduğu söylenebilmektedir.

Tablo 18. Yurttaşların E-Belediyecilik Uygulamaları İle İlgili İçerik Kriterlerine Yönelik Bilgi Düzeylerinin ve Bu Kriterlerin Varlığının E-Belediyecilik Eğilimleri Üzerinde Etkisinin Analizi

\begin{tabular}{|c|c|c|c|c|c|c|c|c|c|c|c|c|c|c|c|}
\hline & \multicolumn{2}{|c|}{$\begin{array}{c}\text { Soruyu } \\
\text { Cevaplayan } \\
\text { atılimcilar }\end{array}$} & \multirow{2}{*}{$\begin{array}{c}\text { Ort. } \\
\%\end{array}$} & \multicolumn{3}{|c|}{ Evet } & \multicolumn{3}{|c|}{ Hayır } & \multicolumn{3}{|c|}{ Kismen } & \multicolumn{3}{|c|}{$\begin{array}{l}\text { Fikrim/ Bilgim } \\
\text { Yok }\end{array}$} \\
\hline & $\mathrm{N}$ & $\%$ & & $\mathrm{~N}$ & $\begin{array}{c}\mathrm{G} \\
(\%)\end{array}$ & $\begin{array}{l}\text { Gçr } \\
(\%)\end{array}$ & $\mathrm{N}$ & \begin{tabular}{c|c|}
$\mathrm{G}$ \\
$(\%)$
\end{tabular} & $\begin{array}{l}\text { Gçr } \\
(\%)\end{array}$ & $\mathrm{N}$ & \begin{tabular}{c|c}
$\mathrm{G}$ \\
$(\%)$ \\
\end{tabular} & $\begin{array}{l}\text { Gçr } \\
(\%)\end{array}$ & $\mathrm{N}$ & $\begin{array}{c}\mathrm{G} \\
(\%)\end{array}$ & $\begin{array}{l}\text { Gçr } \\
(\%)\end{array}$ \\
\hline \begin{tabular}{|l|} 
Bağlı olduğum Belediyenin web sitesinde misyon, \\
vizyon gibi kurum hakkında bilgilere yer verilmiştir.
\end{tabular} & 64 & 10,7 & 1,70 & 49 & 8,2 & 76,6 & 0 & 0 & 0 & 0 & 0 & 0 & 15 & 2,5 & 23,4 \\
\hline $\begin{array}{l}\text { Belediyenin web sitesinde misyon, vizyon gibi bilgilerin } \\
\text { yer alması; bilgi almamı kolaylaştırdığı için, e-bel. tercih } \\
\text { etmemde etkilidir. }\end{array}$ & 64 & 10,7 & 1,66 & 34 & 5,7 & 53,1 & 24 & 4,0 & 37,5 & 0 & 0 & 0 & 6 & 1,0 & 9,4 \\
\hline $\begin{array}{l}\text { Bağlı olduğum belediyenin web sitesinde teşkilat } \\
\text { șemasına yer verilmiştir. }\end{array}$ & 64 & 10,7 & 1,72 & 48 & 8,0 & 75 & 1 & 0,2 & 1,6 & 0 & 0 & 0 & 15 & 2,5 & 23,4 \\
\hline $\begin{array}{l}\text { Belediyenin web sitesinde teşkilat şemasına yer } \\
\text { verilmesi; bilgi almamı kolaylaştırdığı için, e-bel. tercih } \\
\text { etmemde etkilidir. }\end{array}$ & 64 & 10,7 & 1,75 & 34 & 5,7 & 53,1 & 20 & 3,3 & 31,3 & 2 & 0,3 & 3,1 & 8 & 1,3 & 12,5 \\
\hline $\begin{array}{l}\text { Bağlı olduğum belediyenin web sitesinde çalışma } \\
\text { alanlarına yer verilmiştir. }\end{array}$ & 64 & 10,7 & 1,89 & 44 & 7,3 & 68,8 & 1 & 0,2 & 1,6 & 1 & 0,2 & 1,6 & 18 & 3,0 & 28,1 \\
\hline $\begin{array}{l}\text { Belediyenin web sitesinde çalışma alanlarına yer } \\
\text { verilmesi; bilgi almamı kolaylaştırdığı için e-bel. tercih } \\
\text { etmemde etkilidir. }\end{array}$ & 64 & 10,7 & 1,52 & 42 & 7,0 & 65,6 & 15 & 2,5 & 23,4 & 3 & 0,5 & 4,7 & 4 & 0,7 & 6,3 \\
\hline $\begin{array}{l}\text { Bağlı olduğum belediyenin web sitesinde bütçe ve mali } \\
\text { raporlarına yer verilmiştir. }\end{array}$ & 64 & 10,7 & 2,97 & 14 & 2,3 & 21,9 & 12 & 2,0 & 18,8 & 0 & 0 & 0 & 38 & 6,3 & 59,4 \\
\hline $\begin{array}{l}\text { Bağlı olduğum belediyenin web sitesinde bütçe ve mali } \\
\text { raporlara yer verilmesi; bilgi almamı kolaylaştırdığ } 1 \text { için } \\
\text { e-bel. tercih etmemde etkilidir. }\end{array}$ & 64 & 10,7 & 1,69 & 37 & 6,2 & 57,8 & 18 & 3,0 & 28,1 & 1 & 0,2 & 1,6 & 8 & 1,3 & 12,5 \\
\hline $\begin{array}{l}\text { eb sitesinde belediyenin } \\
\text { tir. }\end{array}$ & 64 & 10,7 & 2,88 & 16 & 2,7 & 25 & 12 & 2,0 & 18,8 & 0 & 0 & 0 & 36 & 6,0 & 56,3 \\
\hline $\begin{array}{l}\text { Belediyenin web sitesinde y1llık raporlara yer verilmesi; } \\
\text { bilgi almamı kolaylaştırdığı için, e-bel. tercih etmemde } \\
\text { etkilidir. }\end{array}$ & 64 & 10,7 & 1,64 & 40 & 6,7 & 62,5 & 15 & 2,5 & 23,4 & 1 & 0,2 & 1,6 & 8 & 1,3 & 12,5 \\
\hline $\begin{array}{l}\text { Bağlı olduğum belediyenin web sitesinde stratejik } \\
\text { planlaması ile ilgili bilgiye yer verilmiştir. }\end{array}$ & 64 & 10,7 & 2,59 & 23 & 3,8 & 35,9 & 10 & 1,7 & 15,6 & 1 & 0,2 & 1,6 & 30 & 5,0 & 46,9 \\
\hline $\begin{array}{l}\text { Belediyenin web sitesinde stratejik planlamaya yer } \\
\text { verilmesi; bilgi almamı kolaylaştırdığı için, e-bel. tercih } \\
\text { etmemde etkilidir. }\end{array}$ & 64 & 10,7 & 1,72 & 38 & 6,3 & 59,4 & 15 & 2,5 & 23,4 & 2 & 0,3 & 3,1 & 9 & 1,5 & 14,1 \\
\hline $\begin{array}{l}\text { Bağl1 olduğum belediyenin web sitesinde etkinlik } \\
\text { takvimine yer verilmiştir. }\end{array}$ & 64 & 10,7 & 1,62 & 48 & 8,0 & 75 & 4 & 0,7 & 6,3 & 0 & 0 & 0 & 12 & 2,0 & 18,8 \\
\hline $\begin{array}{l}\text { Belediyenin web sitesinde etkinlik takvimine yer } \\
\text { verilmesi; bilgi almamı kolaylaştırdığı için, e-bel. tercih } \\
\text { etmemde etkilidir. }\end{array}$ & 64 & 10,7 & 1,33 & 50 & 8,3 & 78,1 & 10 & 1,7 & 15,6 & 1 & 0,2 & 1,6 & 3 & 0,5 & 4,7 \\
\hline $\begin{array}{l}\text { Bağlı olduğum belediyenin web sitesinde kurumsal } \\
\text { yayınlara yer verilmiştir. }\end{array}$ & 64 & 10,7 & 1,98 & 38 & 6,3 & 59,4 & 7 & 1,2 & 10,9 & 1 & 0,2 & 1,6 & 18 & 3,0 & 28,1 \\
\hline $\begin{array}{l}\text { Belediyenin web sitesinde kurumsal yayınlara yer } \\
\text { verilmesi; bilgi almamı kolaylaştırdığı için, e-bel. tercih } \\
\text { etmemde etkilidir. }\end{array}$ & 64 & 10,7 & 1,66 & 37 & 6,2 & 57,8 & 19 & 3,2 & 29,7 & 1 & 0,2 & 1,6 & 7 & 1,2 & 10,9 \\
\hline $\begin{array}{l}\text { Bağlı olduğum belediyenin websitesinde güncel iletişim } \\
\text { bilgilerine yer verilmiştir. }\end{array}$ & 64 & 10,7 & 1,36 & 55 & 9,2 & 85,9 & 1 & 0,2 & 1,6 & 2 & 0,3 & 3,1 & 6 & 1,0 & 9,4 \\
\hline $\begin{array}{l}\text { Belediyenin web sitesinde güncel iletişim bilgilerine yer } \\
\text { verilmesi; bilgi almamı kolaylaştırdığı için, e-bel. tercih } \\
\text { etmemde etkilidir. }\end{array}$ & 64 & 10,7 & 1,28 & 55 & 9,2 & 85,9 & 4 & 0,7 & 6,3 & 1 & 0,2 & 1,6 & 4 & 0,7 & 6,3 \\
\hline $\begin{array}{l}\text { Bağlı olduğum belediyenin web sitesinde indirilebilir } \\
\text { dökümanlara yer verilmiștir. }\end{array}$ & 64 & 10,7 & 2,12 & 37 & 6,2 & 57,8 & 4 & 0,7 & 6,3 & 1 & 0,2 & 1,6 & 22 & 3,7 & 34,4 \\
\hline $\begin{array}{l}\text { Belediyenin web sitesinde indirilebilirdökümanların } \\
\text { bulunması, bilgi almamı kolaylaştırdığı için e-bel. tercih } \\
\text { etmemde etkilidir. }\end{array}$ & 64 & 10,7 & 1,55 & 46 & 7,7 & 71,9 & 9 & 1,5 & 14,1 & 1 & 0,2 & 1,6 & 8 & 1,3 & 12,5 \\
\hline
\end{tabular}

Kaynak: Yazarlar tarafından hazırlanmıştır. 
Tablo 18'de görüldüğ̈̈ üzere ankete katılan yurttaşların bağlı bulundukları belediyelerin sağladıkları ebelediyecilik uygulamalarının taşıdığı içeriksel kriterler ile ilgili bilgi düzeylerini ve e-belediyecilik uygulamalarının içeriksel kriterleri taşımasının e-belediyecilik eğilimleri üzerindeki etkisini ölçme amacı taşıyan bu soru, tüm katılımcıların \%10,7'si yani e-belediyecilik hizmetlerini kullandığını belirten katılımcılar tarafından cevaplanmıştır.

Araştırma sonucunda ankete katılan yurttaşların çoğunun "Bağgl olduğum belediyenin web sitesinde misyon, vizyon gibi kurum hakkında bilgilere yer verilmiştir", "Bağll olduğum belediyenin web sitesinde teşkilat şemasına yer verilmiştir", "Bağll olduğum belediyenin web sitesinde çalışma alanlarına yer verilmiştir", "Bă̆ll olduğum belediyenin web sitesinde etkinlik takvimine yer verilmiştir", "Bağll olduğum belediyenin web sitesinde kurumsal yayınlara yer verilmiştir", "Bağll olduğum belediyenin web sitesinde güncel iletişim bilgilerine yer verilmiştir", "Bağll olduğum belediyenin web sitesinde indirilebilir dökümanlara yer verilmiştir"öncüllerine ve bu öncüllere bağlı olarak geliştirilen eğilim öncüllerine“evet" yanıtını verdikleri görülmüştür. Dolayısıyla yurttaşlar açısından e-belediyecilik hizmeti sağladıkları web sitesinin genel olarak içerik kriterlerini karşıladığı ve kriterleri sağlaması dolayısıyla belediyecilik işlemlerini dijital olarak gerçekleştirme eğilimlerinin arttı̆̆ sonucuna ulaşılabilmektedir.

Araştırma sonuçlarına göre, yurttaşların çoğu açısından kullanılabilirlik kriterleri arasında fikir/bilgi sahibi olmadıkları öncüller ise bağlı oldukları belediyenin web sitesinde bütçe ve mali raporları, yıllık raporları, stratejik planlaması ile ilgili öncüllerdir. Bu öncüllere yurttaşların \%59,4, \%56,3 ve \%46,9'luk oranlarla "fikrim/bilgim yok" cevabını verdikleri tespit edilmiş olup, belediyelerin web sitelerinde bu öncüllerdeki kriterlerin sağlanması durumunda, yurttaşların bilgi alma amacıyla e-belediyecilik uygulamalarını tercih etme eğilimlerinin artacağı söylenebilmektedir.

Tablo 19. Yurttaşların E-Belediyecilik Uygulamaları İle İlgili Yurttaşlık ve Sosyal Etkileşim Kriterlerine Yönelik Bilgi Düzeylerinin ve Bu Kriterlerin Varlığının E-Belediyecilik Eğilimleri Üzerinde Etkisinin Analizi

\begin{tabular}{|c|c|c|c|c|c|c|c|c|c|c|c|c|c|c|c|}
\hline & \multicolumn{2}{|c|}{$\begin{array}{c}\text { Soruyu } \\
\text { Cevaplayan } \\
\text { Katılımcilar }\end{array}$} & \multirow{2}{*}{\begin{tabular}{|c|} 
Ort. \\
$\%$ \\
\end{tabular}} & \multicolumn{3}{|c|}{ Evet } & \multicolumn{3}{|c|}{ Hayır } & \multicolumn{3}{|c|}{ Kismen } & \multicolumn{3}{|c|}{$\begin{array}{c}\text { Fikrim/ Bilgim } \\
\text { Yok }\end{array}$} \\
\hline & $\mathrm{N}$ & $\%$ & & $\mathrm{~N}$ & $\begin{array}{c}\mathrm{G} \\
(\%)\end{array}$ & $\begin{array}{l}\text { Gçr } \\
(\%)\end{array}$ & $\mathrm{N}$ & $\begin{array}{c}\mathrm{G} \\
(\%)\end{array}$ & $\begin{array}{l}\text { Gçr } \\
(\%)\end{array}$ & $\mathrm{N}$ & $\begin{array}{l}\mathrm{G} \\
(\%)\end{array}$ & $\begin{array}{l}\text { Gcrr } \\
(\%)\end{array}$ & $\mathrm{N}$ & $\begin{array}{l}\mathrm{G} \\
(\%)\end{array}$ & $\begin{array}{l}\text { Gçr } \\
(\%)\end{array}$ \\
\hline $\begin{array}{l}\text { Yurttaş olarak, seçilen tüm belediye } \\
\text { temsilcilerine e-posta ile } \\
\text { ulaşabiliyorum ve cevap alabiliyorum. }\end{array}$ & 64 & 10,7 & 2,37 & 22 & 3,7 & 34,4 & 17 & 2,8 & 26,6 & 4 & 0,7 & 6,3 & 21 & 3,5 & 32,8 \\
\hline $\begin{array}{l}\text { Seçilen tüm belediye temsilcileri ile e- } \\
\text { posta ile iletişim kurmam, belediye ile } \\
\text { etkileşimimi olumlu etkiler. }\end{array}$ & 64 & 10,7 & 1,22 & 57 & 9,5 & 89,1 & 3 & 0,5 & 4,7 & 1 & 0,2 & 1,6 & 3 & 0,5 & 4,7 \\
\hline $\begin{array}{l}\text { Yurttaş olarak, belediyenin politikaları } \\
\text { hakkında belediyeyle özgürce internette } \\
\text { iletişim kurabiliyorum. }\end{array}$ & 64 & 10,7 & 1,97 & 27 & 4,5 & 42,2 & 22 & 3,7 & 34,4 & 5 & 0,8 & 7,8 & 10 & 1,7 & 15,6 \\
\hline $\begin{array}{l}\text { Belediyenin politikaları hakkında, } \\
\text { kurumla internet üzerinde özgürce } \\
\text { iletişim kurmam; belediye ile } \\
\text { etkileşimimi olumlu etkiler. }\end{array}$ & 64 & 10,7 & 1,25 & 56 & 9,3 & 87,5 & 4 & 0,7 & 6,3 & 0 & 0 & 0 & 4 & 0,7 & 6,3 \\
\hline $\begin{array}{l}\text { Bağlı olduğum belediye, kentle ilgili } \\
\text { politikalar hakkında yurttaşlara } \\
\text { cevrimiçi danışır. }\end{array}$ & 64 & 10,7 & 2,14 & 9 & 1,5 & 14,1 & 44 & 7,3 & 68,8 & 4 & 0,7 & 6,3 & 7 & 1,2 & 10,9 \\
\hline $\begin{array}{l}\text { Bağlı olduğum belediyenin, kentle ilgili } \\
\text { politikalar hakkında yurttaş olarak bana } \\
\text { cevrimiçi ortamlarda danışması, } \\
\text { belediye ile etkileşimimi olumlu etkiler. }\end{array}$ & 64 & 10,7 & 1,08 & 61 & 10,2 & 95,3 & 2 & 0,3 & 3,1 & 0 & 0 & 0 & 1 & 0,2 & 1,6 \\
\hline $\begin{array}{l}\text { Bağlı olduğum belediyenin yurttaş } \\
\text { olarak bana çevirimiçi danışması } \\
\text { beklenti, istek ve taleplerimin yerine } \\
\text { getirilmesini sağlar. }\end{array}$ & 64 & 10,7 & 1,55 & 42 & 7,0 & 65,6 & 14 & 2,3 & 21,9 & 3 & 0,5 & 4,7 & 5 & 0,8 & 7,8 \\
\hline $\begin{array}{l}\text { Bağlı olduğum belediyenin yurttaş } \\
\text { olarak bana çevirimiçi danışması } \\
\text { beklenti, istek ve taleplerimi yerine } \\
\text { getirilmesi; belediye ile etkileşimimi } \\
\text { olumlu etkiler. }\end{array}$ & 64 & 10,7 & 1,06 & 61 & 10,2 & 95,3 & 2 & 0,3 & 3,1 & 1 & 0,2 & 1,6 & 0 & 0 & 0 \\
\hline $\begin{array}{l}\text { Kentle ilgili alınacak kararlarda } \\
\text { çevrimiçi oylama yapabiliyorum. }\end{array}$ & 64 & 10,7 & 2,34 & 10 & 1,7 & 15,6 & 37 & 6,2 & 57,8 & 2 & 0,3 & 3,1 & 15 & 2,5 & 23,4 \\
\hline
\end{tabular}




\begin{tabular}{|c|c|c|c|c|c|c|c|c|c|c|c|c|c|c|c|}
\hline $\begin{array}{l}\text { Kentle ilgili alınacak kararlarda } \\
\text { cevrimiçi oylama yapabilmem, belediye } \\
\text { ile etkileșimimi olumlu etkiler. }\end{array}$ & 64 & 10,7 & 1,17 & 59 & 9,8 & 92,2 & 1 & 0,2 & 1,6 & 2 & 0,3 & 3,1 & 2 & 0,3 & 3,1 \\
\hline $\begin{array}{l}\text { Bağlı olduğum belediyenin sunduğu } \\
\text { hizmetler ile ilgili olarak çevrimiçi } \\
\text { anketlere katılip; değerlendirme } \\
\text { yapabiliyorum. }\end{array}$ & 64 & 10,7 & 2,19 & 15 & 2,5 & 23,4 & 34 & 5,7 & 53,1 & 3 & 0,5 & 4,7 & 12 & 2,0 & 18,8 \\
\hline $\begin{array}{l}\text { Bağl olduğum belediyenin sunduğu } \\
\text { hizmetler ile ilgili olarak çevrimiçi } \\
\text { anketlere kat1lip; değerlendirme } \\
\text { yapabilmem, belediye ile etkileşimimi } \\
\text { olumlu etkiler. }\end{array}$ & 64 & 10,7 & 1,22 & 58 & 9,7 & 90,6 & 1 & 0,2 & 1,6 & 2 & 0,3 & 3,1 & 3 & 0,5 & 4,7 \\
\hline $\begin{array}{l}\text { Yurttaş olarak seçilen tüm belediye } \\
\text { temsilcileriyle saygı sınırları } \\
\text { çerçevesinde yeni medya ortamları } \\
\text { üzerinden iletisisim kurabiliyorum ve } \\
\text { geri dönüş alabiliyorum. }\end{array}$ & 64 & 10,7 & 2,13 & 24 & 4,0 & 37,5 & 20 & 3,3 & 31,3 & 8 & 1,3 & 12,5 & 12 & 2,0 & 18,8 \\
\hline $\begin{array}{l}\text { Yurttas olarak seçilen tüm belediye } \\
\text { temsilcileriyle sayg1 snırları } \\
\text { cerçevesinde yeni medya ortamları } \\
\text { üzerinden iletissim kurabilmem, } \\
\text { belediye ile etkileşimimi olumlu etkiler. }\end{array}$ & 64 & 10,7 & 1,22 & 56 & 9,3 & 87,5 & 4 & 0,7 & 6,3 & 2 & 0,3 & 3,1 & 2 & 0,3 & 3,1 \\
\hline
\end{tabular}

Kaynak: Yazarlar tarafından hazırlanmıştır.

Tablo 19'da görüldüğü üzere, ankete katılan yurttaşların bağlı bulundukları belediyelerin sağladıkları ebelediyecilik uygulamalarının taşıdığı yurttaşlık ve sosyal etkileşim kriterleri ile ilgili bilgi düzeylerini ve ebelediyecilik uygulamalarının bu kriterleri taşımasının e-belediyecilik eğilimleri üzerindeki etkisini ölçme amacı taşıyan bu soru, katılımcıların \%10,7'si yani e-belediyecilik hizmetlerini kullandığını belirten katılımcılar tarafindan cevaplanmiştır.

Araştırma sonucunda katılımcıların "Yurttaş olarak, seçilen tüm belediye temsilcilerine e-posta ile ulaşabiliyorum ve cevap alabiliyorum" şeklinde geliştirilen sorunun birincil öncülüne \%34,4'lük oranla "evet" yanıtını verdikleri görülmüştür. Bu bağlamda, ankete katılan yurttaşların seçilen tüm belediye temsilcileri ile eposta yoluyla iletişim kurabilme ve cevap alabilme oranları; alamama ve bu olanaktan haberdar olmama oranlarından daha yüksek oranda tespit edilmiştir. Aynı sorunun "Seçilen tüm belediye temsilcileri ile e-posta ile iletişim kurmam, belediye ile etkileşimimi olumlu bir etkiler" şeklinde geliştirilen ikinci öncülünü ise; katılımcıların \%89,1'lik oranla "evet" biçiminde yanıtladıkları tespit edilmiştir. Dolayısıyla, bu sonuçlar yurttaşların seçilmiş tüm belediye temsilcileri ile e-posta ile iletişim kurabildiği durumlarda, belediyeyle etkileşimlerinin olumlu yönde etkileneceği biçiminde yorumlanabilmektedir.

Araştırma sonucunda katılımcıların "Yurttaş olarak, belediyenin politikaları hakkında belediyeyle özgürce internette iletişim kurabiliyorum" şeklinde geliştirilen sorunun üçüncü öncülüne \%42,2'lik oranla "evet"yanıtını verdikleri görülmüştür. Bu bağlamda, ankete katılan yurttaşların belediyenin politikaları hakkında belediyeyle özgürce internette iletişim kurabilme oranları, kuramama ve bu olanaktan haberdar olmama oranlarından daha yüksek oranda tespit edilmiştir. Aynı sorunun "Belediyenin politikalarl hakkında, kurumla internet üzerinde özgürce iletişim kurmam; belediye ile etkileşimimi olumlu bir etkiler" şeklinde geliştirilen dördüncü öncülünü ise, katılımcıların \%87,5'lik oranla "evet" şeklinde yanıtladıkları görülmüştür. Dolayısıyla bu sonuçlar, yurttaşların belediye ile İnternet üzerinden özgürce iletişim kurabildiği durumlarda, belediyeyle etkileşimlerinin olumlu yönde etkileneceği biçiminde yorumlanabilmektedir.

Araştırma sonucunda katılımcıların "Bă̆lı olduğum belediye, kentle ilgili politikalar hakkında yurttaşlara çevrimiçi danışı" şeklinde geliştirilen sorunun beşinci öncülüne\% 68,8 'lik oranla "hayır"yanıtını verdikleri görülmüştür. Bu bağlamda, ankete katılan yurttaşların bağlı oldukları belediyelerin kent politikaları hakkında yurttaşlara çevrimiçi danışmadığına yönelik bilgi sahibi olma düzeyleri; danışmasına yönelik bilgi sahibi olma ya da konuyla ilgili bilgi sahibi olmama düzeylerine oranla daha yüksek bir oranda tespit edilmiştir.Aynı sorunun "Bağlı olduğum belediyenin, kentle ilgili politikalar hakkında yurttaş olarak bana çevrimiçi ortamlarda danışması, belediye ile etkileşimimi olumlu bir etkiler" şeklinde geliştirilen altıncı öncülünü ise, katılımcıların \%95,3'lik oranla "evet" biçiminde yanıtladıkları tespit edilmiştir. Dolayısıyla bu sonuçlar, belediyenin, kentle ilgili politikalar hakkında yurttaşlara çevrimiçi ortamlarda danıştığı durumlarda; yurttaşların belediyeyle etkileşimlerinin olumlu yönde etkileneceği biçiminde yorumlanabilmektedir.

Araştırma sonucunda katılımcıların "Bağlı olduğum belediyenin yurttaş olarak bana çevirimiçi danışması beklenti, istek ve taleplerimin yerine getirilmesini sağlar" ş̧eklinde geliştirilen sorunun yedinciöncülüne 
$\% 65,6$ 'lik oranla "evet" yanıtını verdikleri görülmüştür. Bu bağlamda, belediyelerin yurttaş olarak katılımcılara çevrimiçi ortamda danışmasının; katılımcıların beklenti, istek ve taleplerinin yerine getirilmesini sağladığı yönünde olumlu görüş bildiren katılımcıların oranı; bu görüşe katılmayan ve bu konuda herhangi bir fikri/ya da bilgisi olmayan katılımcılara kıyasla daha yüksek bir oranda tespit edilmiştir. Dolayısıyla, bu sonuçlar belediyenin yurttaşlara çevrimiçi danıştığı durumlarda, yurttaşların talep, istek ve beklentilerinin yerine getirilmesi üzerinde olumlu bir etki oluşturacağı biçiminde yorumlanabilmektedir.

Aynı sorunun "Bă̆lı olduğum belediyenin yurttaş olarak bana çevirimiçi danışması beklenti, istek ve taleplerimi yerine getirilmesi; belediye ile etkileşimimi olumlu bir etkiler" şeklindeki sekizinci öncülünü ise; katılımcıların \%95,3'lük oranla "evet" olarak yanıtladıkları görülmüştür. Dolayısıyla bu sonuçlar, belediyenin yurttaşlara çevrimiçi danışmasıyla yurttaşların talep, istek ve beklentilerinin yerine getirildiği durumlarda; yurttaşların belediyeyle etkileşimlerinin olumlu yönde etkileneceği biçiminde yorumlanabilmektedir.

Araştırma sonucunda katılımcıların "Kentle ilgili alınacak kararlarda çevrimiçi oylama yapabiliyorum" şeklinde geliştirilen sorunun dokuzuncu öncülüne; \%57,8'lik oranla "hayır” yanıtını verdikleri görülmüştür. Bu bağlamda, ankete katılan yurttaşların kentle ilgili alınacak kararlarda çevrimiçi oylama yapabilme oranları, yapamama ve bu olanaktan haberdar olmama oranlarından daha düşük oranda tespit edilmiştir. Aynı sorunun "Kentle ilgili alınacak kararlarda çevrimiçi oylama yapabilmem, belediye ile etkileşimimi olumlu bir etkiler" şeklinde geliştirilen onuncu öncülünü ise, katılımcıların \%92,2'lik oranla "evet" olarak yanıtladıkları görülmüştür. Dolayısıyla bu sonuçlar, yurttaşların kentle ilgili alınacak kararlarda çevrimiçi oylama yapabildiği durumlarda, belediyeyle etkileşimlerinin olumlu yönde etkileneceği biçiminde yorumlanabilmektedir.

Araştırma sonucunda katılımcıların "Bağlı olduğum belediyenin sunduğu hizmetler ile ilgili olarak çevrimiçi anketlere katılip; değerlendirme yapabiliyorum" şeklinde geliştirilen sorunun onbirincil öncülüne; \%53,1'lik oranla "hayır" yanıtını verdikleri görülmüştür. Bu bağlamda, ankete katılan yurttaşların bağlı oldukları belediyenin sunduğu hizmetler ile ilgili olarak çevrimiçi anketlere katılıp değerlendirme yapabilme oranları, yapamama oranlarına göre daha düşük bir oranda tespit edilmiştir. Aynı sorunun "Băgll olduğum belediyenin sunduğu hizmetler ile ilgili olarak çevrimiçi anketlere katılıp değerlendirme yapabilmem, belediye ile etkileşimimi olumlu bir etkiler" ş̧eklinde geliştirilen onikinci öncülünü ise, katılımcıların \%90,6'lik oranla "evet" olarak yanıtladıkları görülmüştür. Dolayısıyla bu sonuçlar, yurttaşların bağlı oldukları belediyenin sunduğu hizmetler ile ilgili olarak çevrimiçi anketlere katılıp değerlendirme yapabildiği durumlarda, belediyeyle etkileşimlerinin olumlu yönde etkileneceği biçiminde yorumlanabilmektedir.

Araştırma sonucunda katılımcıların "Yurttaş olarak seçilen tüm belediye temsilcileriyle saygı sınırları çerçevesinde yeni medya ortamlarl üzerinden iletişim kurabiliyorum ve geri dönüş alabiliyorum" şeklinde geliştirilen sorunun onüçüncü öncülüne $\% 37,5$ 'lik oranla "evet", $\% 31,3$ 'lik oranla "hayır", $\% 12,5$ 'lik oranla "kısmen" ve \%18,8'lik oranla "fikrim/bilgim yok" cevabını verdikleri görülmüştür. Bu bağlamda, ankete katılan yurttaşların seçilen tüm belediye temsilcileriyle saygı sınırları çerçevesinde yeni medya ortamları üzerinden iletişim kurabilme ve geri dönüş alma oranları; alamama ve bu olanaktan haberdar olmama oranlarından daha yüksek oranda tespit edilmiştir. Aynı sorunun "Yurttaş olarak seçilen tüm belediye temsilcileriyle saygı sınırları çerçevesinde yeni medya ortamları üzerinden iletişim kurabilmem, belediye ile etkileşimimi olumlu bir etkiler" şeklinde geliştirilen ondördüncü öncülünü ise, katılımcıların \%87,5'lik oranla "evet" olarak yanıtladıkları görülmüş̧ür. Dolayısıyla bu sonuçlar, yurttaşların seçilen tüm belediye temsilcileriyle saygı sınırları çerçevesinde yeni medya ortamları üzerinden iletişim kurabildikleri durumlarda, belediyeyle etkileşimlerinin olumlu yönde etkileneceği biçiminde yorumlanabilmektedir.

Tablo 20. Kocaeli İl ve İlçe Belediyelerinin Mobil Uygulamalarının Mevcudiyetine Yönelik Yurttaşların Bilgi Düzeylerinin Analizi

\begin{tabular}{|l|c|c|c|}
\hline & $\mathrm{N}$ & Genel (\%) & Geçerli (\%) \\
\hline Evet & 28 & 4,7 & 43,8 \\
Hayır & 11 & 1,8 & 17,2 \\
Bilmiyorum & 25 & 4,2 & 39,1 \\
Soruyu Cevaplayan Katılımcilar & 64 & 10,7 & 100 \\
Soruyu Cevaplamayan Katılımcılar & 536 & 89,3 & 0 \\
Toplam & 600 & 100 & - \\
\hline
\end{tabular}

Kaynak: Yazarlar tarafından hazırlanmıştır.

Tablo 20'de görüldüğü üzere, Kocaeli İl ve İlçe Belediyelerinin mobil uygulamalarının mevcudiyetine yönelik yurttaşlarınbilgi düzeylerini ölçme amacı taşıyan bu soru, e-belediyecilik hizmetlerini kullandığını ifade eden 
tüm katılımcıların \%10,7'si tarafından cevaplanmıştır. Bu bağlamda, araştırma sonucunda, bağlı olduğu belediyenin mobil uygulamalarının mevcut olduğunu ifade eden katılımc1ların oranı $\% 43,8$, mevcut olmadığını ifade eden katılımcıların oranı \% 17,2 ve bu konuda bir fikri ya da bilgisi olmadığını belirten katılımcıların oranı \%39,1 olarak tespit edilmiştir. Bu bağlamda, katılımcılardan elde edilen bilgiler doğrultusunda bağlı oldukları belediyelerin mobil uygulamalarının bulunması oranının; bu uygulamaların bulunmamasına kıyasla daha yüksek olduğu sonucuna ulaşılabilmektedir.

Tablo 21. Yurttaşların Belediyelerin Mobil Uygulamalarını Kullanım Düzeylerinin Analizi

\begin{tabular}{|l|c|c|c|}
\hline & N & Genel (\%) & Geçerli (\%) \\
\hline Evet & 22 & 3,7 & 78,6 \\
Hayır & 6 & 1 & 21,4 \\
Soruyu Cevaplayan Katılımcılar & 28 & 4,7 & 100 \\
Soruyu Cevaplamayan Katılımcılar & 572 & 95,3 & 0 \\
Toplam & 600 & 100 & - \\
\hline
\end{tabular}

Kaynak: Yazarlar tarafından hazırlanmıştır.

Tablo 21'de görüldüğü üzere, yurttaşların belediyelerin mobil uygulamalarını kullanma düzeylerini ölçme amacı taşıyan bu soru; tüm katılımcıların \%4,7'si tarafından cevaplanmış olup; \%95,3'ü tarafından cevaplanmamıştır. Katılımcıların bu soruyu cevaplama durumlarına yönelik elde edilen bu dağılım, Tablo20'de elde edilen veriler dikkate alınarak analiz edildiğinde; bağlı oldukları belediyelerin mobil uygulamaları bulunmadığını ya da bu uygulamalara yönelik bilgi/fikir sahibi olmadıklarını ifade eden kullanıcılara bu sorunun yöneltilmemesi ile ilintilidir. $\mathrm{Bu}$ bağlamda araştırma sonucunda, bağlı oldukları belediyelerin mobil uygulamalarının mevcudiyetine yönelik bilgi sahibi olduğunu belirten katılımcıların \%78,6'sinin belediyelerin mobil uygulamalarını kullandıkları, \%21,4'ünün ise bu uygulamaları kullanmadıkları sonucuna ulaşılmıştır.

Tablo 22. Yurttaşların Belediyelerin Mobil Uygulamalarını Kullanım Alanları Analizi

\begin{tabular}{|l|c|c|c|}
\hline & N & Genel (\%) & Geçerli (\%) \\
\hline Tüm hizmet alanları & 6 & 1 & 27,3 \\
Belirli/özel hizmet alanları & 16 & 2,7 & 72,7 \\
Soruyu Cevaplayan Katılımcılar & 22 & 3,7 & 100 \\
Soruyu Cevaplamayan Katılımcılar & 578 & 96,3 & 0 \\
Toplam & 600 & 100 & - \\
\hline
\end{tabular}

Kaynak: Yazarlar tarafından hazırlanmıştır.

Tablo 22'de görüldüğü üzere, yurttaşların belediyelerin mobil uygulamalarını kullanım alanlarını ölçme amacı taşıyan bu soru; tüm katılımcıların \%3,7'si tarafından cevaplanmış olup; \%96,3'ü tarafından cevaplanmamıştır. Katılımcıların bu soruyu cevaplama durumlarına yönelik elde edilen bu dağılım, Tablo 21'de elde edilen veriler dikkate alınarak analiz edildiğinde; bağlı oldukları belediyelerin mobil uygulamalarını kullanmadıklarını belirten kullanıcılara bu sorunun yöneltilmemesi ile ilintilidir. Bu bağlamda araştırma sonucunda, belediyelerin mobil uygulamalarını kullandıklarını ifade eden anket katılımcıların \%27,3'ünün belediyelerin mobil uygulamalarını tüm hizmet alanlarına yönelik işlem yapabilecek şekilde kullandıkları; \%72,7'sinin ise ulaşım, kent-bilgi sistemleri gibi özel hizmet alanlarına yönelik işlem yapmak amacıyla kullandıkları sonucuna ulaşı1mıştır.

Tablo 23. Yurttaşların Belediyelerin Mobil Uygulamaları İle İlgili Memnuniyet Düzeylerinin Analizi

\begin{tabular}{|l|c|c|c|}
\hline & $\mathrm{N}$ & Genel (\%) & Geçerli (\%) \\
\hline Çok memnunum & 5 & 0,8 & 22,7 \\
Memnunum & 12 & 2,1 & 54,5 \\
Kararsızım & 3 & 0,5 & 13,6 \\
Memnun değilim & 2 & 0,3 & 9,1 \\
Hiç Memnun Değilim & 0 & 0 & 0 \\
Soruyu Cevaplayan Katılımcılar & 22 & 3,7 & 100 \\
Soruyu Cevaplamayan Katılımcılar & 578 & 96,3 & 0 \\
Toplam & 600 & 100 & - \\
\hline
\end{tabular}

Kaynak: Yazarlar tarafından hazırlanmıştır.

Tablo 23'de görüldügüü üzere, ankete katılan yurttaşların belediyelerin mobil uygulamalarına yönelik memnuniyet düzeylerini ölçme amacı taşıyan bu soru, mobil uygulama kullandığını ifade eden tüm katılımcıların \%3,7'si tarafından cevaplanmış olup; \%96,3'ü tarafından cevaplanmamıştır. Bu bağlamda, anket 
sonucunda belediyelerin mobil uygulamalarını kullandıklarını ifade eden anket katılımcılarının \%22,7'sinin belediyelerin mobil uygulamalarından çok memnun olduğu, \%54,5'inin memnun olduğu, \%13,6'sinin hizmetleri değerlendirme noktasında kararsız olduğu, \%9, 1'ünün memnun olmadığı sonucuna ulaşılmıştır.

\section{SONUÇ}

Bilgi toplumuna geçiş süreciyle birlikte yeni iletişim teknolojilerinin gelişip yaygınlaşması sonucu, kamu yönetim anlayışında yeni bir paradigma olarak karşımıza çıkan e-yönetişim, kamu ve paydaş gruplar arasında işbirliği ve etkileşim temelinde kamusal hizmetlerin etkin ve etkili sunumunu temel almakta, kamusal hizmet sunumunun yerel düzeydeki en önemli temsilcileri olan belediyeler ve yurttaşlar için olumlu kazanımlar sağlamaktadır. Belediyeler ve yurttaşlar açısından olumlu kazanımlar sağlayan e-yönetişim uygulamalarının her iki tarafa da fayda sağlayacak biçimde geliştirilip sürdürülmesine katkı sunmak amacıyla yurttaşlar tarafından bilgi, farkındalık ve kullanım düzeylerinin belirlenmesi gerekmektedir. Bu çalışmada, Kocaeli il ve ilçe belediyelerinin e-yönetişim bağlamında yeni medya ortamlarında sundukları hizmetlere yönelik yurttaşların bilgi, farkındalık ve kullanım düzeyleri incelenmiştir. Bu doğrultuda, Kocaeli ili sınırları içerisinde ikamet eden 600 kişiyle yüz yüze anket çalışması gerçekleştirilmiş olup, ankete katılan yurttaşların büyük çoğunluğunun 2650 yaş aralığında, ortaokul mezunu, evli ve erkek olduğu tespit edilmiştir.

Araştırma sonuçlarına göre, yurttaşların yürütülen hizmetler doğrultusunda belediyelerle iletişim kurmadıkları, iletişim kuran yurttaşların ise, daha çok yüzyüze görüşme ve internet aracıllğıyla iletişim kurdukları görülmüştür. Yurttaşların e-belediyecilik uygulamalarına yönelik bilgi ve kullanım düzeylerine bakıldığında ise, genel olarak düşük olduğu tespit edilmiştir. Bilgi ve kullanım düzeylerindeki bu düşüklük, yurttaşların ebelediyecilik kullanmama nedenleriyle de açıklanmaktadır. Yurttaşlar, belediye ve yetkilileriyle internette iletişime geçme ihtiyaçlarının olmaması, ilgili web siteleri ve İnternet hizmetlerinin varlığından haberdar olmaması, belediye hizmetlerini karşılamak için İnternet kullanmaya ihtiyaç duymaması, İnternet hizmetlerine güven duymaması gibi nedenlerle e-belediyecilik hizmetlerini kullanmamaktadır.

E-belediyecilik hizmetlerini kullandığını belirten yurttaşların ise, bu hizmetleri daha çok kullanım kolaylığı, daha hızlı hizmet sağlanması, daha güvenilir olması, hizmet çeşitliliğinin fazla olması, içerik olarak daha fazla bilgiye yer verilmesi ve etkileşime daha açık bir yapıya sahip olması gerekçeleriyle kullandıkları tespit edilmiştir. Araştırma verilerine bağlı olarak e-belediyecilik hizmetlerini kullandığını belirten yurttaşların bu hizmetleri kullanım alanları daha çok ulaşım, hizmet karşılığı alınacak ücret ve cezalar, konut edinme, imar ve istimlak ve kültür-sanat olarak karşımıza çıkmaktadır. Genel olarak yurttaşların e-belediyecilik uygulamalarından memnun oldukları görülmüştür.

Yurttaşların e-belediyecilik uygulamaları ile ilgili bilgi, gizlilik/güvenlik, kullanılabilirlik, içerik, yurttaşlık ve sosyal etkileşim kriterlerine yönelik bilgi düzeyleri ve tutumlarının da sorgulandığ 1 araştırma sonucunda; yurttaşların bağlı bulundukları belediyelerin sağladıkları e-belediyecilik uygulamalarının içeriği, kullanılabilirliği ve etkileşimi ile ilgili bilgi düzeylerinin genel olarak yüksek olduğu ve bu kriterlerin varlığının yurttaşların e-belediyecilik uygulamalarına yönelik tutumlarında olumlu etkisi olduğu tespit edilmiştir. Ancak yurttaşların e-belediyecilik uygulamalarının gizlilik/güvenlik kriterlerini sağlama durumuyla ilgili fikir/bilgi sahibi olmadıkları görülmüş olup, e-belediyecilik uygulamalarının gizlilik ve güvenlik kriterlerini sağlaması durumunda e-belediyeciliğe yönelik tutumları üzerinde olumlu etki yaratacağı ortaya çıkmıştır.

Araştırma sonuçları genel olarak değerlendirildiğinde ise, Kocaeli il ve ilçe belediyelerinin e-yönetişim bağlamında yeni medya ortamlarında sundukları hizmetlere yönelik yurttaşların bilgi, farkındalık ve kullanım düzeylerinin düşük olduğu ortaya çıkmaktadır. Bu bağlamda, belediyeler ve yurttaşlar açısından olumlu kazanımlar sağlayan e-yönetişim uygulamalarının yurttaşlar tarafından bilinmemesi, bilinse de ihtiyaca cevap vermemesi ve dolayısıyla kullanılmaması e-yönetişimin uygulanması ve işlerlik kazanması noktasında temel bir sorun olarak karşımıza çıkmaktadır.

Durum saptayıcı bir araştırma olarak planlanan bu çalışma, yurttaşların e-yönetişim hizmetlerine yönelik bilgi, farkındalık ve kullanım durumlarını Kocaeli ili üzerinden somutlaması açısından alana katkıda bulunmakla birlikte, Türkiye'de yeni medya ortamlarında verilen kamu hizmetleriyle ilgili yerel çalışmalar için sürecin sağlıklı yönde geliştirilmesi, e-yönetişim uygulamalarının her iki tarafa da fayda sağlayacak biçimde geliştirilip sürdürülebilmesi için bu uygulamalara yönelik yurttaşların bilgi ve farkındalığını artıracak çalışmaların planlanması ve bilgi toplumuna geçiş aşamasında gerekli olan dijital becerilerin arttırılmasına yönelik programlar için yol gösterici bir nitelik taşımaktadır. 
Çalışmadan elde edilen sonuçlar doğrultusunda aşağıdaki önerilerde bulunulabilir:

- Araştırma, Kocaeli il ve ilçe belediyeleri ile sınırlandırılmış olup, evrenin tamamını kapsamamaktadır. Bu bağlamda, araştırma sonuçları Kocaeli il ve ilçe belediyelerini kapsamakta, dolayısıyla genelleştirme yapılamamaktadır. Bundan sonraki çalışmalarda, aynı bölge içindeki belediyelere yönelik, farklı bölgelere ait belediyelere yönelik, büyükşsehir belediyelerine yönelik araştırmalar yapılabilir ve sonuçlar karşılaştırılabilir.

- Çalışmada, yurttaşların belediyelerin yeni medya ortamlarında sunmuş oldukları e-yönetişim hizmetleri ile ilgili bilgi, farkındalık ve kullanım düzeylerini ölçmek amacıyla araştırma yönetimi olarak anket kullanılmıştır. Bundan sonra yapılacak çalışmalarda daha detaylı veri elde edebilmek amacıyla anket çalışmasına ek olarak yurttaşlarla derinlemesine görüşme ya da odak grup görüşmeleri gerçekleştirilebilir; yurttaşların dijital beceri durumları deneysel araştırmalarla ölçümlenebilir.

\section{KAYNAKÇA}

ASİA, Jaya (1988), Asian Americans in Higher Education and at Work, Lawrence Erlbaum Associates, Hillsdale, NJ.

BACKSTROM, Charles H. ve HURSH-CESAR, Gerald (1981), Survey Research, Macmilla, New York, 2.Bask1.

BİLGíli, Alper (2015), “Türkiye'de Yerel Yönetimlerde E-Devlet Olgusu: Nilüfer Belediyesi E-Belediyecilik Uygulamaları", 9. Kamu Yönetimi Sempozyumu (KAYSEM) Bildiriler Kitabı, TODAİE Yayınları, Ankara, ss.213-222.

BOZKURT, Ömer, ERGUN, Turgay ve SEZEN, Seriye (1998), Kamu Yönetimi Sözlüğü, TODAİE Yayınları, Ankara.

CHEN, Yu-Che ve GANT, John (2001), "Transforming E-Governmentservices: The Use of Application Service Providers in US Local Governments", Government Information Quarterly, S.18(4), ss.343-355.

ÇAVUŞ, Süleyman (2011), "Yeni Illetişim Teknolojilerinden İnternet ve Halkla İlişkilerdeki Yerinin İncelenmesi: Talas Belediyesi Örneği”, Yayımlanmamış Yüksek Lisans Tezi, Erciyes Üniversitesi Sosyal Bilimler Enstitüsü, Kayseri.

ÇORUH, Mustafa (2009), “Türkiye'de e-Belediye Araştırma Sonuçları”, İNET-TR'09 - XIV. Türkiye'de İnternet Konferansi Kitabı, 11-13 Aralık 2009, Bilgi Üniversitesi Yayını, İstanbul. http://inettr.org.tr/inetconf14/bildiri/2.pdf (Erişim Tarihi: 05.02.2017).

DEMİRL, Demokaan (2010), "Yönetişimde Yeni Bir Boyut: E-Yönetişim”, Türk İdare Dergisi, S.466, ss.6594.

DOĞU, İlknur (2008), "Halkla İlişkilerde Yeni İletişsim Teknolojilerinin Kullanılması: Kadıköy ve Beyoğlu İlçe Belediyelerinin Kurumsal Web Sitesi Analizi”, Yayımlanmamış Yüksek Lisans Tezi, Kocaeli Üniversitesi Sosyal Bilimler Enstitüsü, Kocaeli.

DURNA, Ufuk ve ÖZEL, Mehmet (2008), “Bilgi Çağında Bir Yönetsel Dönüşüm Yaklaşımı: E-(YEREL) Yönetim”, Mustafa Kemal Üniversitesi Sosyal Bilimler Enstitüsü Dergisi, S.5(10), ss.1-32.

GORDON, Thomas F. (2012), "eGovernance and its Value for Public Administration", E-Article, https://pdfs. semanticscholar.org/5687/eaabcd2b88a15514f8e1442ee39a77cc5ac1.pdf (Erişim Tarihi: 15.06.2016).

GÜLER, Birgül Ayman (2001), "Yerel Yönetimler ve İnternet”, inet-tr'2001, Türkiye'de İnternet Konferansları VII, 1-3 Kasım, 2001, İstanbul. http://www.inettr.org.tr/inetconf7/Sunum/yerelyonetim.doc (Erişim Tarihi: 09.02.2017).

HOLZER, Marc ve MANOHARAN, Aroon P.(2016), "Digital Governance in Municipalities Worldwide (201516)", E-Article,

https://spaa.newark.rutgers.edu/sites/default/files/files/EGov/Publications/Digital\%20Governance \%20in\%20Municipalities\%20Worldwide\%20(2015-16).pdf (Erişim Tarihi: 01.04.2017). 
KABAKUŞ, Ahmet Kamil (2014), "Türkiye'deki Büyükşsehirlerin Illçe Belediyelerine Göre E-Belediye Hizmetlerinde Etkinliğinin Veri Zarflama Analizi ile Ölçülmesi”, Atatürk Üniversitesi Sosyal Bilimler Enstitüsü Dergisi, S.18(3),ss.307-324.

KANUNGO, Shivraj (2004), "On The Emancipatory Role of Rural Information Systems", Information Technology and People, S.17(4), ss.407-422.

KARADUMAN, Murat ve KARADUMAN, Sibel (2004), "Yerel Yönetimlerde E-Belediyecilik Uygulamalart: İzmir ve Antalya Büyükşehir Belediyesi Web Sitesi Analizi", Yerel Yönetimler Kongresi: Dünden Bugüne Yerel Yönetimlerde Yeniden Yapılanma Bildiriler Kitabı, Çanakkale, ss.371-382.

KAYA BENGSIR, Türksel (2000), “Web'deki Belediyelerimiz: Ankara Büyükşehir Belediyesi”, Çağdaş Yerel Yönetimler Dergisi, S.9(2), ss.76-90.

KAYA BENGSİR, Türksel (2002), “Web’deki Belediyelerimiz: Eskişehir Büyükşehir Belediyesi”, Çağdaş Yerel Yönetimler Dergisi, S.11(1), ss.107-124.

LETHBRIDGE, Jane (2015), "Digitalisation of local authority services in Europe", A Briefing Paper Commissioned by EPSU/CEMR, https://www.epsu.org/sites/default/files/article/files/Lethbridge\%20 Digitalisation\%20of\%20local\%20authority\%20services\%20in\%20Europe.pdf/ (Erişim Tarihi: 17.09.2017).

NEGİZ, Nilüfer (2011), "Elektronik Dönüşüm Karşısında Vatandaş Deneyimi: Isparta Belediyesi İncelemesi”, Selçuk Üniversitesi İïBF Dergisi, S.21, ss.499-533.

NOHUTÇU, Ahmet ve DEMİREL, Demokaan (2005), "Türkiye'de e-Devlet Uygulamaları", Türk İdare Dergisi, S.477, ss.35-56.

ÖKMEN, Mustafa, YILMAZ, Abdullah ve BAŞARAN, Serdar (2004), “Kamu Yönetiminde Yeni Yaklaşımlar ve Bir Yönetişim Faktörü Olarak Yerel Yönetimler", Kamu Yönetimi (Ed. Mustafa Ökmen, Abdullah Y1lmaz), Gazi Kitabevi, Ankara, ss.23-80.

ÖZER, Mehmet Akif (2017), "Yönetişimden Dijital Yönetişsime: Paradigma Değişsiminin Teknolojik Boyutu”, HAK-iș Uluslararası Emek ve Toplum Dergisi, S.6(16), ss.457-479.

ÖZÜPEK, M. Nejat (2010), "Belediyelerin Halkla İlişkiler Çalışmalarında İnternet Kullanımı: Büyükşehir Web Siteleri Üzerine Uygulamalı Bir Çalışma", Selçuk Üniversitesi İletişim Fakültesi Dergisi, S.6(3), ss.196-205.

SARAÇBAŞI, Yasemin (2010), "Türkiye'de E-Belediyecilik Uygulamalarında Belediye Vatandaş Ilişskisi: Malatya Belediyesi Örneği”, Yayımlanmamış Yüksek Lisans Tezi, Süleyman Demirel Üniversitesi Sosyal Bilimler Enstitüsü, Isparta.

SERENLİ, Abdullah (2013), "Türkiye'de Yerel Yönetimlerin E-Devlet Uygulamaları Kapsamında Büyükşehir Belediyeleri Web Sitelerinin İşlevselliği", ISDAM Dergisi, S.2013/May1s, ss.1-20, http://www.isdam.org.tr/img/151673112018_ 22767275577.pdf (Erişim Tarihi: 17.06.2019).

SOBACI, Mehmet Zahid ve ALTIOK, Ramazan (2011), "Türkiye'de Büyükşehir Belediyelerinin E-Katılım Uygulamaları: Website İçerik Analizi”, VIII. Kamu Yönetimi Forumu: Kamu Yönetimi ve Teknoloji, TODAİE Yayınları, Ankara, ss.786-803.

SUE, Valerie M. ve RITTER, Lois A. (2012), Conducting Online Surveys, Sage Publications, Los Angeles.

ŞAHİN, Ali (2007), “Kamu Çalı̧̧anlarının E-Devleti Algılayış Biçimleri: Beklentiler ve Sorunlar”, Kamu Yönetimi Yazıları (Ed. Bilal Eryılmaz, Musa Eken, Mustafa Lütfi Şen), Nobel Yayın Dağıtım, Ankara, ss.512-542.

ŞAT, Nur (2016), “Türkiye'de Büyükşehir Belediyelerinin Genel Ăg (Web) Sitelerinin Analizi”, Türk İdare Dergisi, S.482, ss.183-236.

TANYILDIZI, Nural İmik ve KARATEPE, Selma (2011), "Belediyelerin Halkla İlişkiler Çalışmalarında Web Siteleri: Ikki Farklı Ülke ve İki Farklı Belediye Analizi”, E- Journal of New World Sciences Academy (NWSA), S.6(3), ss.520-538. 
TARHAN, Ahmet (2012), "Büyükşehir Belediyelerinin Sosyal Medya Uygulamalarına Halkla İlişkiler Modellerinden Bakmak", Gazi Üniversitesi İletişim Fakültesi Kuram ve Araştırma Dergisi, S.35, ss.79-101.

TEJASVEE, Sanjay, S.S.SARANGDEVOT, Devendra Gahlot ve SANDAL, Shruti (2010), "E-Governance and Effective Deliverance of Information and Services to Citizens Architecture", International Journal of Computer Science and Information Technologies, S.1(4), ss.298-302.

YERELİ, Ahmet Burçin, ATSAN, Emre ve KIZILTAN, Mustafa (2015), "Yolsuzlukla Mücadelede E-Yönetişim ve Kirgızistan'daki Durum", Manas Sosyal Araştırmalar Dergisi, S.4(1), ss.129- 150.

YILDIRIM, Ali ve ŞIMŞEK, Hasan (1999), Sosyal Bilimlerde Nitel Araştırma Yöntemleri, Seçkin Yayınları, Ankara.

YILDIRIM, Murat (2010), E-Devlet ve Yurttaş Odaklı Kamu Yönetimi, Nobel Yayın Dağıtım, Ankara.

YSK - YÜKSEK SEÇİM KURULU (2017), "Seçmen İstatistikleri", YSK Kurumsal Web Sayfası, www.ysk.gov.tr (Erişim Tarihi: 06.01.2017).

ZEREN, Halim Emre, SEBETCI, Özel ve KOÇAK Yüksel (2015), "E-Devlet ve E-Belediye Hizmetleri Çerçevesinde Aydın Halkının Katılma Duyarlılığının Ölçülmesi”, Kafkas Üniversitesi İktisadi ve İdari Bilimler Fakültesi Dergisi, S.6(9), ss.249-268. 